\title{
Organocatalytic Entry to Chiral Bicyclo[3.n.1]alkanones via Direct Asymmetric Intramolecular Aldolization
}

\author{
Noriaki Itagaki, Mari Kimura, Tsutomu Sugahara, and Yoshiharu Iwabuchi \\ Graduate School of Pharmaceutical Sciences, Tohoku University \\ Aobayama, Sendai 980-8578, Japan \\ Fax: $+81-22-795-6845$ \\ E-mail: iwabuchi@mail.pharm.tohoku.ac.jp
}

\section{Supporting Information}

Table of Contents

1. General

2. Experimental Procedures

(1) Preparation of substrates for the aldol reactions

S-2

(2) Typical procedures for the asymmetric aldol reactions

S-6

(3) Conversion of (-)- $\mathbf{2 a}$ to known (-)- $\mathbf{6}$ and determination of the absolute structure

(4) Preparation of the catalysts for the aldol reaction

(5) Preparation of _-branched ketoaldehyde 1c 


\section{General.}

$\mathrm{IBX}^{1}$ and Dess-Martin periodinane ${ }^{2}$ were prepared according to the literature procedures. Other chemicals and solvents were purchased from commercial suppliers or purified by standard techniques. All reactions were stirred magnetically, under an argon atmosphere, unless otherwise noted, and monitored with analytical TLC (Merck Kieselgel $60 \quad F_{254}$ ). Column chromatography was carried out with silica gel 60 particle size $0.063-0.210 \mathrm{~mm}$. Melting points were taken with Yazawa BY-2 and are uncorrected. NMR spectra were measured in JEOL JNM-AL400 (400 MHz). Chemical shifts were reported in the b scale relative to tetramethylsilane (TMS) as $0.00 \mathrm{ppm}$ for ${ }^{1} \mathrm{H}\left(\mathrm{CDCl}_{3}\right)$ and residual $\mathrm{CHCl}_{3}$ (7.26 ppm for ${ }^{1} \mathrm{H}$ and $77.00 \mathrm{ppm}$ for ${ }^{13} \mathrm{C}$ ), as internal reference. The infrared (IR) spectra were recorded on JASCO IR-700 or JASCO FT/IR-410. Mass spectra were measured on JEOL JMS-DX303 (for low resolution MS) and JMS-AX500 or JMS-700 (for high resolution MS) instruments. The specific rotations were measured on JASCO DIP-370. Elemental analyses utilized Yanaco CHN CORDER MT-6. HPLC utilized Gilson Model 307 or Gilson Model 305 with Gilson Model 112 or Gilson Model 119 as UV-detector (254 nm).

\section{Experimental procedures.}

(1) Preparation of substrates for the aldol reactions

3-(4-hydroxycyclohexyl)propionic acid ethyl ester: 5\% (w/w) Rh/C (5.5 g) was added to a solution of ethyl p-hydroxycinnamate $(55.94 \mathrm{~g}, 291.2 \mathrm{mmol})$ in ethyl acetate $(310 \mathrm{ml})$ and the mixture was stirred under atmospheric pressure of $\mathrm{H}_{2}$ for 10 days at room temperature. Then, the reaction mixture was filtered through a Celite pad eluting with ethyl acetate, and concentrated under reduced pressure. The residue was purified by silica gel column chromatography [hexane-AcOEt $(3: 1 \mathrm{v} / \mathrm{v})$ ] to afford hydroxyester $(58.20 \mathrm{~g}, 100 \%$, cis:trans $=1: 1)$ as a colorless oil.

cis-isomer : IR (neat): $3439,1736 \mathrm{~cm}^{-1} ;{ }^{1} \mathrm{H}-\mathrm{NMR}\left(400 \mathrm{MHz}, \mathrm{CDCl}_{3}\right)$ b: 4.11 (q, 2H, $J=7.1 \mathrm{~Hz}$ ), 3.96 (br.s, $1 \mathrm{H}), 2.31$ (t, $2 \mathrm{H}, J=7.8 \mathrm{~Hz}), 1.75-1.48(\mathrm{~m}, 9 \mathrm{H}), \quad 1.44-$ $1.30(\mathrm{~m}, 3 \mathrm{H}) .1 .25(\mathrm{t}, 3 \mathrm{H}, J=7.2 \mathrm{~Hz}) ;{ }^{13} \mathrm{C}-\mathrm{NMR}\left(100 \mathrm{MHz}, \mathrm{CDCl}_{3}\right)$ b: 173.9, 66.4, 60.0, 35.6, 31.83, 31.78, 30.8, 26.4, 14.0; MS m/z : $182\left(\mathrm{M}^{+}-\mathrm{H}_{2} \mathrm{O}\right), 136$ (100\%); HRMS Calcd. $\mathrm{C}_{11} \mathrm{H}_{18} \mathrm{O}_{2}\left(\mathrm{M}^{+}-\mathrm{H}_{2} \mathrm{O}\right): 182.1306$. Found: 182.1306. 
trans-isomer : IR (neat): 3408, $1733 \mathrm{~cm}^{-1}$; ${ }^{1} \mathrm{H}-\mathrm{NMR}\left(400 \mathrm{MHz}, \mathrm{CDCl}_{3}\right.$ ) b: 4.11 (q, $2 \mathrm{H}, J=7.2 \mathrm{~Hz}$ ), 3.50 (m, 1H), 3.22 (br.s, 1H), 2.30 (t, 2H, J = $7.8 \mathrm{~Hz}), 1.95$ (m, 2H), $1.76(\mathrm{~m}, 2 \mathrm{H}), 1.52(\mathrm{q}, 2 \mathrm{H}, J=7.6 \mathrm{~Hz}), 1.28-1.15(\mathrm{~m}, 3 \mathrm{H}) .1 .25(\mathrm{t}, 3 \mathrm{H}, J=7.2$ $\mathrm{Hz}$ ), 0.95 (qd, 3H, $J=7.2 \mathrm{~Hz}) ;{ }^{13} \mathrm{C}-\mathrm{NMR}\left(100 \mathrm{MHz}, \mathrm{CDCl}_{3}\right.$ ) b: 173.7, 70.2, 59.9, 35.9, 34.8, 31.8, 31.2, 30.6, 13.8; MS m/z : $200\left(\mathrm{M}^{+}\right), 136$ (100\%); HRMS Calcd. $\mathrm{C}_{11} \mathrm{H}_{20} \mathrm{O}_{3}: 200.1411$. Found: 200.1404

4-(3-hydroxypropyl)cyclohexanol: $\mathrm{LiAlH}_{4}(193 \mathrm{mg}, 5.09 \mathrm{mmol})$ was added to a stirred solution of 3-(4-hydroxycyclohexyl)propionic acid ethyl ester (1.06 g, 5.29 mmol, cis: trans $=2: 1$ ) in THF at $0{ }^{\circ} \mathrm{C}$ and the mixture was stirred for $4 \mathrm{~h}$ at room temperature. Then, $\mathrm{H}_{2} \mathrm{O}(0.20 \mathrm{ml})$ and $15 \%$ aqueous $\mathrm{NaOH}(0.20 \mathrm{ml})$ was dropped to the reaction mixture at $0{ }^{\circ} \mathrm{C}$, and stirring was continued for $10 \mathrm{~min}$ at the same temperature. Additional $\mathrm{H}_{2} \mathrm{O}(0.60 \mathrm{ml})$ was dropped to the reaction mixture and further stirring was continued for $30 \mathrm{~min}$ at $0{ }^{\circ} \mathrm{C}$. After $\mathrm{MgSO}_{4}$ was added, the reaction mixture was filtered through a Celite pad and concentrated under reduced pressure. The residue was purified by silica gel column chromatography [hexane-AcOEt $(1: 1 \mathrm{v} / \mathrm{v})$ ] to afford diol $(800 \mathrm{mg}, 96 \%)$ as a colorless solid.

mp 90-91 ${ }^{\circ} \mathrm{C}$. IR $\left(\mathrm{CHCl}_{3}\right.$ solution): $3348 \mathrm{~cm}^{-1} ;{ }^{1} \mathrm{H}-\mathrm{NMR}\left(400 \mathrm{MHz}, \mathrm{CDCl}_{3}\right.$ ) b: 3.92 (s, $0.67 \mathrm{H}), 3.58(\mathrm{~s}, 2 \mathrm{H}), 3.52(\mathrm{~m}, 0.34 \mathrm{H}), 2.78$ (br.s, $2 \mathrm{H}), 1.95$ (d, $0.66 \mathrm{H} \mathrm{J}=12.7$ $\mathrm{Hz}), 1.80-1.15(\mathrm{~m}, 11.7 \mathrm{H}), 0.94(\mathrm{q}, 0.67 \mathrm{H}, J=11.5 \mathrm{~Hz}) ; \mathrm{MS} m / z: 158\left(\mathrm{M}^{+}\right), 81$ (100\%); HRMS Calcd. $\mathrm{C}_{9} \mathrm{H}_{18} \mathrm{O}_{2}: 158.1306$. Found: 158.1271.

3-(4-oxocyclohexyl)propionaldehyde (1a): $\mathrm{N}$-methylmorpholine $\mathrm{N}$-oxide (2.28 g, $19.4 \mathrm{mmol}$ ) was added to a mixture of 4-(3-hydroxypropyl)cyclohexanol (1.00 $\mathrm{g}, 6.32 \mathrm{mmol})$ and molecular sieves $4 \AA(1.30 \mathrm{~g})$ in $\mathrm{CH}_{2} \mathrm{Cl}_{2}(33 \mathrm{ml})$ and the mixture was stirred for $10 \mathrm{~min}$ at room temperature. Then, tetrapropylammonium perruthenate $(114 \mathrm{mg}, 0.324 \mathrm{mmol})$ was added to the reaction mixture at $0{ }^{\circ} \mathrm{C}$ and stirring was continued for $2 \mathrm{~h}$ at room temperature. The reaction mixture was filtered through a Celite pad and concentrated under reduced pressure. The crude mixture was purified by silica gel column chromatography [hexane-AcOEt $(17: 3 \mathrm{v} / \mathrm{v})]$ to afford ketoaldehyde $1 \mathrm{a}(695 \mathrm{mg}, 71 \%)$ as a colorless oil. 
IR (neat): $1719 \mathrm{~cm}^{-1} ;{ }^{1} \mathrm{H}-\mathrm{NMR}\left(400 \mathrm{MHz}, \mathrm{CDCl}_{3}\right.$ ) b: $9.80(\mathrm{t}, 1 \mathrm{H}, \mathrm{J}=1.6 \mathrm{~Hz}), 2.53$ (td, $2 \mathrm{H}, J=7.4,1.5 \mathrm{~Hz}), 2.45-2.28(\mathrm{~m}, 4 \mathrm{H}), 2.06(\mathrm{~m}, 2 \mathrm{H}), 1.80-1.65(\mathrm{~m}, 3 \mathrm{H}), 1.43$ $(\mathrm{m}, 2 \mathrm{H}) ;{ }^{13} \mathrm{C}-\mathrm{NMR}\left(100 \mathrm{MHz}, \mathrm{CDCl}_{3}\right)$ b: 211.1, 201.6, 41.3, 40.2, 35.1, 32.1, 27.2; MS m/z: $154\left(\mathrm{M}^{+}\right), 55$ (100\%); HRMS Calcd. $\mathrm{C}_{9} \mathrm{H}_{14} \mathrm{O}_{2}:$ 154.0993. Found: 154.0998.

8-ethoxycarbonylmethylidene-1,4-dioxaspiro[4.5]decane: Triethylphosphonoacetate $(14.0 \mathrm{ml}, 70.57 \mathrm{mmol}$ ) was added to a suspension of $\mathrm{NaH}(60 \%)$ $(2.83 \mathrm{~g}, 70.8 \mathrm{mmol})$ in THF $(270 \mathrm{ml})$ at $0{ }^{\circ} \mathrm{C}$ and the mixture was stirred for 30 min at the same temperature. Then, to the mixture was dropped 1,4cyclohexanedione monoethylene acetal $(10.05 \mathrm{~g}, 64.35 \mathrm{mmol})$ in THF $(65 \mathrm{ml})$ at $0{ }^{\circ} \mathrm{C}$ and stirring was continued for $40 \mathrm{~min}$ at the same temperature. After addition of $\mathrm{H}_{2} \mathrm{O}$, the mixture was extracted with $\mathrm{Et}_{2} \mathrm{O}$. The aqueous layer was extracted with AcOEt and the combined organic solution was washed with brine, dried over $\mathrm{MgSO}_{4}$, and concentrated under reduced pressure. The crude mixture was purified by silica gel column chromatography [hexane-AcOEt $(9: 1 \mathrm{v} / \mathrm{v})$ ] to afford _, '-unsaturated ester (14.63 g, $100 \%)$ as a colorless oil.

IR (neat): $1731 \mathrm{~cm}^{-1}$; ${ }^{1} \mathrm{H}-\mathrm{NMR}\left(400 \mathrm{MHz}, \mathrm{CDCl}_{3}\right.$ ) b: $5.66(\mathrm{~s}, 1 \mathrm{H}), 4.15$ (q, 2H, J = $7.2 \mathrm{~Hz}$ ), $3.98(\mathrm{~s}, 4 \mathrm{H}), 3.00(\mathrm{t}, 2 \mathrm{H}, J=6.6 \mathrm{~Hz}), 2.37(\mathrm{t}, 2 \mathrm{H}, J=6.6 \mathrm{~Hz}), 1.76(\mathrm{~m}$, $4 \mathrm{H}), 1.27$ (t, 3H, J = 7.1 Hz); ${ }^{13} \mathrm{C}-\mathrm{NMR}\left(100 \mathrm{MHz}, \mathrm{CDCl}_{3}\right)$ b: 166.4, 160.0, 114.2, 107.9, 64.4, 59.6, 35.7, 35.0, 34.6, 26.0, 14.3; MS m/z : $226\left(\mathrm{M}^{+}\right), 226(100 \%)$; HRMS Calcd. $\mathrm{C}_{12} \mathrm{H}_{18} \mathrm{O}_{4}: 226.1205$. Found: 226.1185.

8-ethoxycarbonylmethyl-1,4-dioxaspiro[4.5]decane: 10\% (w/w) Pd/C (285 $\mathrm{mg}$ ) was added to a solution of 8-ethoxycarbonylmethylidene-1,4dioxaspiro[4.5]decane (2.85 g, $12.6 \mathrm{mmol})$ in AcOEt (25 ml) and the mixture was stirred under atmospheric pressure of $\mathrm{H}_{2}$ for $2 \mathrm{~h}$ at room temperature. Then, the reaction mixture was filtered through a Celite pad eluting with AcOEt, and concentrated under reduced pressure to afford ester $(2.87 \mathrm{~g}, 100 \%)$ as a colorless oil.

IR (neat): $1718 \mathrm{~cm}^{-1} ;{ }^{1} \mathrm{H}-\mathrm{NMR}$ (400 MHz, $\mathrm{CDCl}_{3}$ ) b: 4.12 (q, $2 \mathrm{H}, J=7.2 \mathrm{~Hz}$ ), 3.94 (s, 4H), $2.20(\mathrm{~d}, 2 \mathrm{H}, J=7.1 \mathrm{~Hz}), 1.84(\mathrm{~m}, 1 \mathrm{H}), 1.74(\mathrm{~m}, 4 \mathrm{H}), 1.55(\mathrm{td}, 2 \mathrm{H}, J=$ 13.7, 3.7 Hz), $1.32(\mathrm{~m}, 2 \mathrm{H}), 1.25(\mathrm{t}, 3 \mathrm{H}, J=7.1 \mathrm{~Hz}) ;{ }^{13} \mathrm{C}-\mathrm{NMR}\left(100 \mathrm{MHz}, \mathrm{CDCl}_{3}\right)$ 
b: 172.8, 108.5, 64.2, 60.2, 41.0, 34.3, 33.5, 30.0, 14.3; MS m/z : $228\left(\mathrm{M}^{+}\right), 99$ (100\%). HRMS Calcd. $\mathrm{C}_{12} \mathrm{H}_{20} \mathrm{O}_{4}: 228.1362$. Found : 228.1355.

8-(2-hydroxyethyl)-1,4-dioxaspiro[4,5]decane: A solution of 8ethoxycarbonylmethyl-1,4-dioxaspiro[4.5]decane $(1.30 \mathrm{~g}, 5.71 \mathrm{mmol})$ in THF $(13.0 \mathrm{ml})$ was dropped to a stirred suspention of $\mathrm{LiAlH}_{4}(163 \mathrm{mg}, 4.30 \mathrm{mmol})$ in THF $(10.0 \mathrm{ml})$ at $0{ }^{\circ} \mathrm{C}$ and the mixture was stirred for $4 \mathrm{~h}$ at room temperature. Then, $\mathrm{H}_{2} \mathrm{O}(0.2 \mathrm{ml})$ and $15 \%$ aq. $\mathrm{NaOH}(0.6 \mathrm{ml})$ was dropped to the reaction mixture at $0{ }^{\circ} \mathrm{C}$, and stirring was continued for $10 \mathrm{~min}$ at the same temperature. Additional $\mathrm{H}_{2} \mathrm{O}(0.6 \mathrm{ml})$ was dropped to the reaction mixture and further stirring was continued for $30 \mathrm{~min}$ at $0{ }^{\circ} \mathrm{C}$. After the addition of $\mathrm{MgSO}_{4}$, the reaction mixture was filtered through a Celite pad and concentrated under reduced pressure. The residue was purified by silica gel column chromatography [hexane-AcOEt (2:1-1:1 v/v)] to afford ketalalcohol (1.07 g, $100 \%)$ as a colorless oil.

4-(2-hydroxyethyl)cyclohexanone: $10 \%$ aq. $\mathrm{HCl}(4.6 \mathrm{ml})$ was dropped to a solution of 8-(2-hydroxyethyl)-1,4-dioxaspiro[4,5]decane (566 mg, $3.03 \mathrm{mmol}$ ) in THF $(9.2 \mathrm{ml})$ at $0{ }^{\circ} \mathrm{C}$ and the mixture was stirred for $24 \mathrm{~h}$ at room temperature. After neutralization with $\mathrm{K}_{2} \mathrm{CO}_{3}$, the reaction mixture was extracted with AcOEt. The aqueous layer was extracted with AcOEt and the combined organic solution was washed with brine, dried over $\mathrm{MgSO}_{4}$, and concentrated under reduced pressure. The crude mixture was purified by silica gel column chromatography [hexane-AcOEt (4:1 v/v)] to afford hydroxyketone $(418 \mathrm{mg}, 97 \%)$ as a colorless oil.

(4-oxocyclohexyl)acetaldehyde (1b): To a solution of oxalyl chloride $(1.90 \mathrm{ml}$, $1.31 \mathrm{mmol})$ in $\mathrm{CH}_{2} \mathrm{Cl}_{2}(80.0 \mathrm{ml})$ was added a solution DMSO $(3.0 \mathrm{ml}, 42.3 \mathrm{mmol})$ in $\mathrm{CH}_{2} \mathrm{Cl}_{2}(10.0 \mathrm{ml})$ at $-78{ }^{\circ} \mathrm{C}$ and the mixture was stirred for $5 \mathrm{~min}$ at the same temperature. A solution of 4-(2-hydroxyethyl)cyclohexanone $(1.00 \mathrm{~g}, 7.04$ $\mathrm{mmol})$ in $\mathrm{CH}_{2} \mathrm{Cl}_{2}(20.0 \mathrm{ml})$ was added to the reaction mixture at $-78{ }^{\circ} \mathrm{C}$ and stirring was continued for $15 \mathrm{~min}$ at the same temperature. To the mixture was added $\mathrm{Et}_{3} \mathrm{~N}(8.8 \mathrm{ml}, 63.1 \mathrm{mmol})$, and the mixture was further stirred for $30 \mathrm{~min}$ at the same temperature. Then, the reaction mixture was warmed to room temperature and $\mathrm{H}_{2} \mathrm{O}$ was added, and the mixture was extracted with AcOEt. 
The aqueous layer was extracted with AcOEt and the combined organic solution was washed with brine, dried over $\mathrm{MgSO}_{4}$, and concentrated under reduced pressure. The crude mixture was purified by silica gel column chromatography [hexane-AcOEt (9:1-4:1 v/v)] to afford ketoaldehyde $\mathbf{1 b}(782 \mathrm{mg}, 80 \%)$ as a colorless oil.

IR (neat): $1712 \mathrm{~cm}^{-1} ;{ }^{1} \mathrm{H}-\mathrm{NMR}\left(400 \mathrm{MHz}, \mathrm{CDCl}_{3}\right.$ ) b: 9.81 (t, $1 \mathrm{H}, J=1.5 \mathrm{~Hz}$ ), 2.50-2.35 (m, 7H), $2.10(\mathrm{~m}, 2 \mathrm{H}), 1.49(\mathrm{~m}, 2 \mathrm{H}) ;{ }^{13} \mathrm{C}-\mathrm{NMR}\left(100 \mathrm{MHz}, \mathrm{CDCl}_{3}\right)$ b: 210.6, 200.9, 49.3, 40.5, 32.4, 30.5; MS m/z : $140\left(\mathrm{M}^{+}\right)$, 96 (100\%); HRMS Calcd. $\mathrm{C}_{8} \mathrm{H}_{12} \mathrm{O}_{2}: 140.0837$. Found: 140.0807 .

(2) Typical procedures for the asymmetric aldol reactions

(1S,5R,8R)-8-hydroxybicyclo[3.3.1]nonan-2-one [(-)-2a]: A solution of ketoaldehyde 1a (100 mg, $0.648 \mathrm{mmol})$ in $\mathrm{MeCN}(2.6 \mathrm{ml})$ was added dropwisely to a stirred solution of tetrabutylammonium 4-TBDPSoxy-L-prolinate $(21.5 \mathrm{mg}$, $0.033 \mathrm{mmol})$ in $\mathrm{MeCN}(2.6 \mathrm{ml})$ at room temperature. The reaction mixture was stirred for $3 \mathrm{~h}$ at room temperature. Then, the mixture was concentrated under reduced pressure and the residue was purified by silica gel column chromatography [hexane-AcOEt (4:1 v/v)] to afford hydroxyketone (-)-2a (77 mg, $77 \%)$ as colorless needles. An aliquot sample was recrystallized from diisopropyl ether-hexane.

$\mathrm{mp} 131-133{ }^{\circ} \mathrm{C} ;\left[{ }_{\mathrm{D}}\right]_{\mathrm{D}}{ }^{31}=-3.57^{\circ}\left(\mathrm{c} 0.8, \mathrm{CHCl}_{3}\right)$. [lit. ${ }^{3}$ for the enantiomer [ $]_{\mathrm{D}}{ }^{20}=$ $+3.6^{\circ}$ (c 0.65, $\left.\mathrm{CHCl}_{3}\right)$ ]; IR ( $\mathrm{CHCl}_{3}$ solution): $3520,1700 \mathrm{~cm}^{-1} ;{ }^{1} \mathrm{H}-\mathrm{NMR}(400 \mathrm{MHz}$, $\left.\mathrm{CDCl}_{3}\right)$ b: $3.78(\mathrm{~m}, 1 \mathrm{H}), 2.79$ (br. s, $\left.1 \mathrm{H}\right), 2.66(\mathrm{~s}, 1 \mathrm{H}), 2.54(\mathrm{~m}, 1 \mathrm{H}), 2.37(\mathrm{~m}, 1 \mathrm{H})$, 2.18-2.05 (m, 3H), $1.97(\mathrm{~m}, 1 \mathrm{H}) 1.69(\mathrm{~m}, 4 \mathrm{H}), 1.38(\mathrm{~m}, 1 \mathrm{H}) ;{ }^{13} \mathrm{C}-\mathrm{NMR}(100 \mathrm{MHz}$, $\left.\mathrm{CDCl}_{3}\right)$ b: 216.3, 71.6, 51.6, 39.0, 31.0, 30.7, 29.7, 26.7, 24.9; MS m/z: $154\left(\mathrm{M}^{+}\right)$, 70 (100\%); HRMS Calcd. $\mathrm{C}_{9} \mathrm{H}_{14} \mathrm{O}_{2}:$ 154.0993. Found: 154.0983; Anal. Calcd. for $\mathrm{C}_{9} \mathrm{H}_{14} \mathrm{O}_{2}$ : C, 70.10; $\mathrm{H}, 9.15$. Found: C, 70.05; H, 9.13.

The diastereomeric purity of this aldol product $2 \mathrm{a}$ was determined to be $98 \%$ de by $400 \mathrm{MHz}{ }^{1} \mathrm{H}-\mathrm{NMR}$ spectra. The signals used for the analysis were the signals due to the C8-bonding protons of the diastereomers. Chemical shifts of the peaks appears as follows; endo-alcohol b : $3.80(\mathrm{~m}, 1 \mathrm{H})$, exo-alcohol b : $4.06(\mathrm{~m}$, $1 \mathrm{H})$.

The enantiomeric purity of $(-)-2 \mathrm{a}$ was determined to be $94 \%$ ee by (a) ${ }^{1} \mathrm{H}-\mathrm{NMR}$ 
spectra using Mosher's method ${ }^{4}$ and (b) chiral HPLC analysis after conversion of $2 a$ to the corresponding benzoyl ester.

(a) Mosher's method: Hydroxyketone (-)-2a was converted into the corresponding ( $S$ )-MTPA ester by treatment with $(R)$-MTPA chloride and pyridine in $\mathrm{CH}_{2} \mathrm{Cl}_{2}$ with a small amount of 4-dimethylaminopyridine as catalyst and analyzed by the $400 \mathrm{MHz}{ }^{1} \mathrm{H}-\mathrm{NMR}$ spectroscopy in $\mathrm{CDCl}_{3}$. The signals used for the analysis of the MTPA ester of $(-)$-2a were the signals due to the methoxy protons of the corresponding (S)-MTPA ester. Chemical shifts of the peaks used were as follows; $(R)$-MTPA ester of $(-)-2 \mathrm{a} b$ : $3.57(\mathrm{~d}, 3 \mathrm{H}, J=1.0 \mathrm{~Hz}),(S)$-MTPA ester of (-)-2a b : $3.48(\mathrm{~d}, 3 \mathrm{H}, J=1.0 \mathrm{~Hz})$.

(b) Chiral HPLC analysis: Hydroxyketone (-)-2a was converted into the corresponding benzoyl ester by treatment with benzoyl chloride and $\mathrm{Et}_{3} \mathrm{~N}$ in $\mathrm{CH}_{2} \mathrm{Cl}_{2}$ with a small amount of 4-dimethylaminopyridine as catalyst and analyzed by HPLC using DAICEL CHIRALCEL OD. The conditions used for the analysis of the benzoyl ester of (-)-2a and the retention time were as follows; Solvent: $i$ $\mathrm{PrOH}$-hexane (3:97). Flow rate: $0.5 \mathrm{ml} / \mathrm{min}$. Retention time: benzoyl ester of $(1 S, 5 R, 8 R)-2 \mathbf{a} ; 20.6 \mathrm{~min}$, benzoyl ester of $(1 R, 5 S, 8 S)-2 \mathbf{a} ; 23.5 \mathrm{~min}$

(1S,5R,7R)-7-hydroxy-bicyclo[3.2.1]octan-2-one $\quad(2 b): \quad A$ solution of ketoaldehyde 1b $(50.0 \mathrm{mg}, 0.36 \mathrm{mmol})$ in DMSO $(1.9 \mathrm{ml})$ was added dropwisely to a stirred solution of tetrabutylammonium -L-aspartate (34 $\mathrm{mg}, 0.090 \mathrm{mmol}$ ) in DMSO $(1.0 \mathrm{ml})$ at room temperature and stirring was continued for $24 \mathrm{~h}$ at the same temperature. Then, the reaction mixture was diluted with $\mathrm{Et}_{2} \mathrm{O}$ and the organic solution was washed by $\mathrm{H}_{2} \mathrm{O}$. The aqueous layer was extracted with $\mathrm{Et}_{2} \mathrm{O}$ several times and the combined organic solution was washed with brine, dried over $\mathrm{MgSO}_{4}$, and concentrated under reduced pressure. The residue was purified by silica gel column chromatography [hexane-AcOEt $(17: 3 \mathrm{v} / \mathrm{v})$ ] to afford hydroxyketone $\mathbf{2 b}(20.0 \mathrm{mg}, 40 \%)$ as a colorless solid.

mp 121-122 ${ }^{\circ} \mathrm{C}$; IR $\left(\mathrm{CHCl}_{3}\right.$ solution): 3406, $1695 \mathrm{~cm}^{-1}$; ${ }^{1} \mathrm{H}-\mathrm{NMR}(400 \mathrm{MHz}$, $\left.\mathrm{CDCl}_{3}\right)$ b: $4.61(\mathrm{~m}, 1 \mathrm{H}), 3.40$ (br. s, $\left.1 \mathrm{H}\right), 2.78(\mathrm{t}, 1 \mathrm{H}, J=5.1 \mathrm{~Hz}), 2.62(\mathrm{~m}, 1 \mathrm{H})$, 2.47-2.25 (m, 3H), 1.94-1.67 (m, 4H), $1.57(\mathrm{~m}, 1 \mathrm{H}) ;{ }^{13} \mathrm{C}-\mathrm{NMR}\left(100 \mathrm{MHz}, \mathrm{CDCl}_{3}\right)$ b:212.5, 74.0, 57.8, 36.5, 36.4, 36.1, 33.5, 31.6; MS m/z : $140\left(\mathrm{M}^{+}\right), 80(100 \%)$; HRMS Calcd. $\mathrm{C}_{8} \mathrm{H}_{12} \mathrm{O}_{2}: 140.0837$. Found: 140.0807 . 
The diastereomeric purity of this aldol product $\mathbf{2} \mathbf{b}$ was determined to be $98 \%$ de by $400 \mathrm{MHz}{ }^{1} \mathrm{H}-\mathrm{NMR}$ spectra. The signals used for the analysis were the signals due to the C7-bonding protons of the diastereomers. Chemical shifts of the peaks appears as follows; endo-alcohol b : $4.61(\mathrm{~m}, 1 \mathrm{H})$, exo-alcohol b : $4.40(\mathrm{~m}$, $1 \mathrm{H})$.

The enantiomeric purity of $\mathbf{2} \mathbf{b}$ was determined to be $33 \%$ ee by $400 \mathrm{MHz}{ }^{1} \mathrm{H}$ NMR spectra using Mosher's method ${ }^{4}$ as described above. The absolute configuration of $\mathbf{2} \mathbf{b}$ was determined to be $(1 S, 5 R, 7 R)$ by comparison of the specific optical rotation after conversion of $\mathbf{2 b}$ to a known bicyclooctenone $13^{5}$ as shown in the following scheme.

\section{Scheme 1}

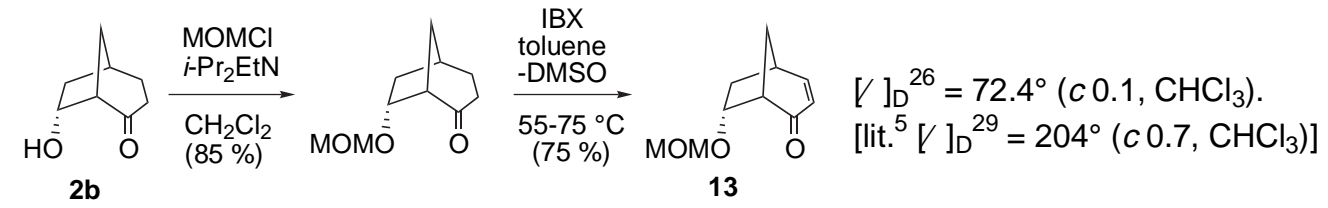

(3) Conversion of $(-)-2 a$ to known $(-)-6^{6}$ and determination of the absolute structure

(1S,5S,8R)-8-hydroxybicyclo[3.3.1]non-3-en-2-one (4): TBDPSCl (0.593 ml, $2.28 \mathrm{mmol}$ ) and imidazole $(310 \mathrm{mg}, 4.55 \mathrm{mmol}$ ) were added to a solution of alcohol (-)-endo-2a (293 mg, $1.90 \mathrm{mmol},>99 \%$ ee) in DMF (3.8 ml) at room temperature. The reaction mixture was stirred for $18 \mathrm{~h}$ at the same temperature. Then, the reaction mixture was diluted with $\mathrm{Et}_{2} \mathrm{O}$ and washed with $\mathrm{H}_{2} \mathrm{O}$. The aqueous layer was extracted with $\mathrm{Et}_{2} \mathrm{O}$ and the combined organic extract was washed with brine, dried over $\mathrm{MgSO}_{4}$, and concentrated under reduced pressure. The crude mixture was purified by silica gel column chromatography [hexaneAcOEt $(19: 1 \mathrm{v} / \mathrm{v})$ ] to afford TBDPS ether as a colorless oil. To a solution of this TBDPS ether in toluene-DMSO $(20 \mathrm{ml}, 2: 1 \mathrm{v} / \mathrm{v})$ was added IBX $(2.13 \mathrm{~g}, 7.60$ $\mathrm{mmol}$ ). The mixture was heated to $55-75^{\circ} \mathrm{C}$ and stirred for $16 \mathrm{~h}$. After cooling, the reaction mixture was diluted with $\mathrm{Et}_{2} \mathrm{O}$, filtered through a Celite pad, and the organic solution was washed with saturated aqueous $\mathrm{NaHCO}_{3}$ and $\mathrm{H}_{2} \mathrm{O}$. The aqueous layer was extracted with $\mathrm{Et}_{2} \mathrm{O}$ and the combined organic solution was washed with brine, dried over $\mathrm{MgSO}_{4}$, and concentrated under reduced pressure. 
The crude mixture was purified by silica gel column chromatography [hexaneAcOEt $(19: 1 \mathrm{v} / \mathrm{v})$ ] to afford enone as a colorless oil. Next, 1.0 M TBAF in THF $(5.7 \mathrm{ml}, 5.7 \mathrm{mmol})$ was added dropwisely to a solution of this enone in THF (5.0 $\mathrm{ml}$ ) at room temperature and the mixture was stirred for $20 \mathrm{~h}$ at the same temperature. After removal of the solvent under reduced pressure, AcOEt was added to this residue, and the organic solution was washed with $\mathrm{H}_{2} \mathrm{O}$. The aqueous layer was extracted with AcOEt and the combined organic solution was washed with brine, dried over $\mathrm{MgSO}_{4}$, and concentrated under reduced pressure. The crude mixture was purified by silica gel column chromatography [hexaneAcOEt $(4: 1 \mathrm{v} / \mathrm{v})$ ] to afford hydroxyenone 4 as a colorless solid (130 mg, $45 \%$ ).

(1S,5S)-bicyclo[3.3.1]non-3-ene-2,8-dione [(+)-5]: Dess-Martin periodinane (725 mg) was added to a solution of alcohol 4 (120 mg, $0.788 \mathrm{mmol})$ in $\mathrm{CH}_{2} \mathrm{Cl}_{2}$ $(5.3 \mathrm{ml})$ at room temperature and the mixture was stirred for $2 \mathrm{~h}$ at the same temperature. Then, the reaction mixture was diluted with $\mathrm{Et}_{2} \mathrm{O}$, filtered through a Celite pad, and the organic solution was washed with saturated aqueous $\mathrm{NaHCO}_{3}$ and $\mathrm{H}_{2} \mathrm{O}$. The aqueous layer was extracted with $\mathrm{Et}_{2} \mathrm{O}$ and the combined organic solution was washed with brine, dried over $\mathrm{MgSO}_{4}$, and concentrated under reduced pressure. The crude mixture was purified by silica gel column chromatography [hexane-AcOEt $(4: 1 \mathrm{v} / \mathrm{v})$ ] to afford enedione $(+)-5$ (99 mg, $84 \%$ ) as a colorless solid.

$\mathrm{mp}$ 64.5-65.5 ${ }^{\circ} \mathrm{C}$;. [ L $_{\mathrm{D}}{ }^{28}=+312.5^{\circ}$ (c 1.36, $\left.\mathrm{CHCl}_{3}\right)$; IR $\left(\mathrm{CHCl}_{3}\right.$ solution): 1750 , $1705 \mathrm{~cm}^{-1}$. ${ }^{1} \mathrm{H}-\mathrm{NMR}\left(400 \mathrm{MHz}, \mathrm{CDCl}_{3}\right)$ b: $7.18(\mathrm{~m}, 1 \mathrm{H}), 6.21(\mathrm{~d}, 1 \mathrm{H}, J=10.0 \mathrm{~Hz})$, $3.42(\mathrm{~d}, 1 \mathrm{H}, J=1.5 \mathrm{~Hz}), 2.86(\mathrm{~m}, 1 \mathrm{H}), 2.67-2.57(\mathrm{~m}, 2 \mathrm{H}), 2.46(\mathrm{dd}, 1 \mathrm{H}, J=16.1$, $5.4 \mathrm{~Hz}$ ), 2.27-2.17 (m, 2H), $2.09(\mathrm{~m}, 1 \mathrm{H}) ;{ }^{13} \mathrm{C}-\mathrm{NMR}\left(100 \mathrm{MHz}, \mathrm{CDCl}_{3}\right)$ b: 202.4, 193.1, 152.4, 129.0, 63.0, 35.7, 34.7, 29.7, 28.1.; MS m/z : $150\left(\mathrm{M}^{+}\right), 55$ (100\%). HRMS Calcd. $\mathrm{C}_{9} \mathrm{H}_{10} \mathrm{O}_{2}: 150.0680$. Found : 150.0700 .

(R)-3-(4-Oxocyclohex-2-enyl)propionic acid ethyl ester [(-)-6]: A solution of $0.26 \mathrm{M} \mathrm{NaOEt}$ in EtOH $(0.615 \mathrm{ml}, 0.160 \mathrm{mmol})$ was added dropwisely to a solution of enedione $(+)-5(20.0 \mathrm{mg}, 0.133 \mathrm{mmol})$ in $\mathrm{EtOH}(1.0 \mathrm{ml})$ at $-30{ }^{\circ} \mathrm{C}$ and the mixture was stirred for $45 \mathrm{~min}$ at the same temperature. Then, the reaction mixture was quenched with saturated aqueous $\mathrm{NH}_{4} \mathrm{Cl}$ solution and extracted 
with $\mathrm{Et}_{2} \mathrm{O}$. The aqueous layer was extracted with $\mathrm{Et}_{2} \mathrm{O}$ and the combined organic solution was washed with brine, dried over $\mathrm{MgSO}_{4}$, and concentrated under reduced pressure. The residue was purified by silica gel column chromatography [hexane-AcOEt (9:1 v/v)] to afford ester (-)-6 (23.0 mg, $88 \%)$ as a colorless oil. []$_{\mathrm{D}}{ }^{32}=-88.2^{\circ}\left(c 0.25, \mathrm{CHCl}_{3}\right)\left[\right.$ [lit. $^{6}[]_{\mathrm{D}}=-81.9^{\circ}\left(c 1.15, \mathrm{CHCl}_{3}\right)$ ]; IR (neat): 1733, $1681 \mathrm{~cm}^{-1}$. ${ }^{1} \mathrm{H}-\mathrm{NMR}\left(400 \mathrm{MHz}, \mathrm{CDCl}_{3}\right.$ ) b: $6.83(\mathrm{~m}, 1 \mathrm{H}), 6.00$ (dd, $1 \mathrm{H}, J=10.2,2.4$ $\mathrm{Hz}), 4.16(\mathrm{q}, 2 \mathrm{H}, J=7.2 \mathrm{~Hz}), 2.54-2.32(\mathrm{~m}, 5 \mathrm{H}), 2.13(\mathrm{~m}, 1 \mathrm{H}), 1.88(\mathrm{~m}, 1 \mathrm{H})$, 1.80-1.65 (m, 2H), $1.27(\mathrm{t}, 3 \mathrm{H}, J=7.2 \mathrm{~Hz}) ;{ }^{13} \mathrm{C}-\mathrm{NMR}\left(100 \mathrm{MHz}, \mathrm{CDCl}_{3}\right)$ b: 199.4 , 173.0, 153.6, 129.5, 60.6, 36.7, 35.3, 31.5, 29.5, 28.2, 14.2; MS m/z: $196\left(\mathrm{M}^{+}\right)$, 109 (100\%). HRMS Calcd. $\mathrm{C}_{11} \mathrm{H}_{16} \mathrm{O}_{3}:$ 196.1099. Found : 196.1089.

(4) Preparation of the catalysts for the aldol reaction

\section{Schme 2}

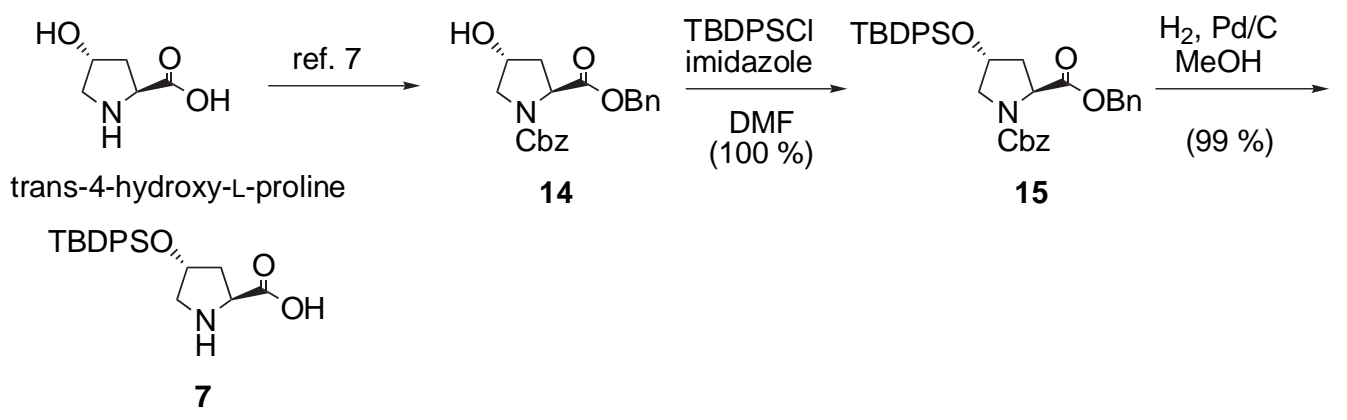

(2S,4R)-4-(tert-butyldiphenylsiloxy)pyrrolidine-1,2-dicarboxylic

acid dibenzyl ester [(-)-15]: TBDPSCl (10.8 ml, $41.6 \mathrm{mmol})$ and imidazole $(5.67 \mathrm{~g}$, $82.3 \mathrm{mmol})$ were added to a solution of alcohol 14 (12.36 g, $34.8 \mathrm{mmol})$ in DMF $(35 \mathrm{ml})$ at room temperature. The reaction mixture was stirred for $12 \mathrm{~h}$ at the same temperature. Then, the reaction mixture was diluted with $\mathrm{Et}_{2} \mathrm{O}$ and the organic solution was washed with $\mathrm{H}_{2} \mathrm{O}$. The aqueous layer was extracted with $\mathrm{Et}_{2} \mathrm{O}$ and the combined organic solution was washed with brine, dried over $\mathrm{MgSO}_{4}$, and concentrated under reduced pressure. The crude mixture was purified by silica gel column chromatography [hexane-AcOEt $(19: 1 \mathrm{v} / \mathrm{v})$ ] to afford silyl ether (-)-15 (20.77 g, $100 \%)$ as a colorless oil. []$_{\mathrm{D}}{ }^{29}=-18.9^{\circ}\left(\mathrm{c} 0.8, \mathrm{CHCl}_{3}\right.$ ); IR (neat): $1745,1711 \mathrm{~cm}^{-1} ;{ }^{1} \mathrm{H}-\mathrm{NMR}(400 \mathrm{MHz}$, 
$\mathrm{CDCl}_{3}$ ) b: $7.63-7.10(\mathrm{~m}, 2 \mathrm{H}), 5.20-5.02\left(\mathrm{~m}, 3 \mathrm{H}_{\text {rotamer }}\right), 4.95\left(\mathrm{~d}, 0.5 \mathrm{H}_{\text {rotamer }}, J=12.2\right.$ $\mathrm{Hz}$ ), $4.88\left(\mathrm{~d}, 0.5 \mathrm{H}_{\text {rotamer }}, J=12.4 \mathrm{~Hz}\right), 4.62$ and 4.53 (each t, total $1 \mathrm{H}_{\text {rotamer }}$, each $J$ = $7.7 \mathrm{~Hz}), 4.41$ (br.s, $1 \mathrm{H},), 3.63-3.42(\mathrm{~m}, 2 \mathrm{H}), 2.26(\mathrm{~m}, 1 \mathrm{H}), 1.89(\mathrm{~m}, 1 \mathrm{H}), 1.03$ and 1.01 (each s, total $9 \mathrm{H}_{\text {rotamer }}$ ); ${ }^{13} \mathrm{C}-\mathrm{NMR}\left(100 \mathrm{MHz}, \mathrm{CDCl}_{3}\right.$ ) (rotamer) b: 172.2 , $172.0,154.9$, 154.1, 136.4, 136.3, 135.4, 135.2, 133.2, 133.1, 133.0, 132.9, $129.78,129.77,129.74,128.33,128.27,128.23,128.12,128.0,127.93,127.89$, $127.78,127.76,127.67,127.65,127.62,77.3,71.4,70.6,67.0,66.7,66.6,58.2$, 58.0, 54.9, 54.5, 39.5, 38.6, 26.8, 26.7, 19.0; MS m/z: $536\left(\mathrm{M}^{+}-\mathrm{C}_{4} \mathrm{H}_{9}\right), 492$ (100\%). HRMS Calcd. $\mathrm{C}_{32} \mathrm{H}_{30} \mathrm{NO}_{5} \mathrm{Si}\left(\mathrm{M}^{+}-\mathrm{C}_{4} \mathrm{H}_{9}\right): 536.1891$. Found : 536.1912 .

(4R)-4-(tert-butyldiphenylsilyloxy)-L-proline [(-)-7]: 10\% (w/w) Pd/C (1.20 g) was added to a solution of estercarbamate (-)-15 (11.99 g, $20.2 \mathrm{mmol})$ in $\mathrm{MeOH}$ $(110 \mathrm{ml})$ and the mixture was stirred under atmospheric pressure of $\mathrm{H}_{2}$ for $12 \mathrm{~h}$ at room temperature. Then, the reaction mixture was filtered through a Celite pad eluting with $\mathrm{MeOH}$, and concentrated under reduced pressure to afford amino acid (-)-7 (7.38 g, $99 \%)$ as a colorless solid. An aliquot sample was recrystallized from $\mathrm{MeOH}-\mathrm{Et}_{2} \mathrm{O}$-hexane to provide colorless needles .

mp 214-215 ${ }^{\circ} \mathrm{C}$;. [ $]_{\mathrm{D}}{ }^{28}=-36.3^{\circ}\left(\mathrm{c} 0.8, \mathrm{CH}_{3} \mathrm{OH}\right)$. [lit. ${ }^{8}\left[{ }_{\mathrm{D}}\right]_{\mathrm{D}}{ }^{23}=-33.3^{\circ}$ (c 1.08, $\mathrm{CH}_{3} \mathrm{OH}$ )]; IR (nujol): 3458, $1613 \mathrm{~cm}^{-1}$. ${ }^{1} \mathrm{H}-\mathrm{NMR}\left(400 \mathrm{MHz}, \mathrm{CD}_{3} \mathrm{OD}\right)$ b: 7.67-7.63 (m, 4H), 7.49-7.40 (m, 6H), 4.60 (br.s, $1 \mathrm{H}), 4.27$ (dd, $1 \mathrm{H}, J=10.5,7.6 \mathrm{~Hz}$ ), 3,34$3.30(\mathrm{~m}, 1 \mathrm{H}), 3.20$ (dd, $1 \mathrm{H}, J=12.2,1.5 \mathrm{~Hz}$ ), $2.34(\mathrm{dd}, 1 \mathrm{H}, J=13.7,7.3 \mathrm{~Hz}$ ), 1.94 (ddd, $1 \mathrm{H}, J=14.1,10.5,3.9 \mathrm{~Hz}), 1.09$ (s, 9H); ${ }^{13} \mathrm{C}-\mathrm{NMR}\left(100 \mathrm{MHz}, \mathrm{CD}_{3} \mathrm{OD}\right)$ b: 173.6, 136.7, 133.9, 131.2, 128.9, 74.0, 61.5, 54.5, 40.0, 27.4, 19.8; MS m/z : $312\left(\mathrm{M}^{+}-\mathrm{C}_{4} \mathrm{H}_{9}\right), 312(100 \%)$. HRMS Calcd. $\mathrm{C}_{17} \mathrm{H}_{18} \mathrm{NO}_{3} \mathrm{Si}\left(\mathrm{M}^{+}-\mathrm{C}_{4} \mathrm{H}_{9}\right): 312.1055$. Found : 312.1039; Anal. Calcd. for $\mathrm{C}_{21} \mathrm{H}_{27} \mathrm{NO}_{3} \mathrm{Si}$ : C, 68.26; H, 7.36; N, 3.79. Found: C, 67.88; $\mathrm{H}, 7.31 ; \mathrm{N}, 3.75$. 


\section{Schme 3}

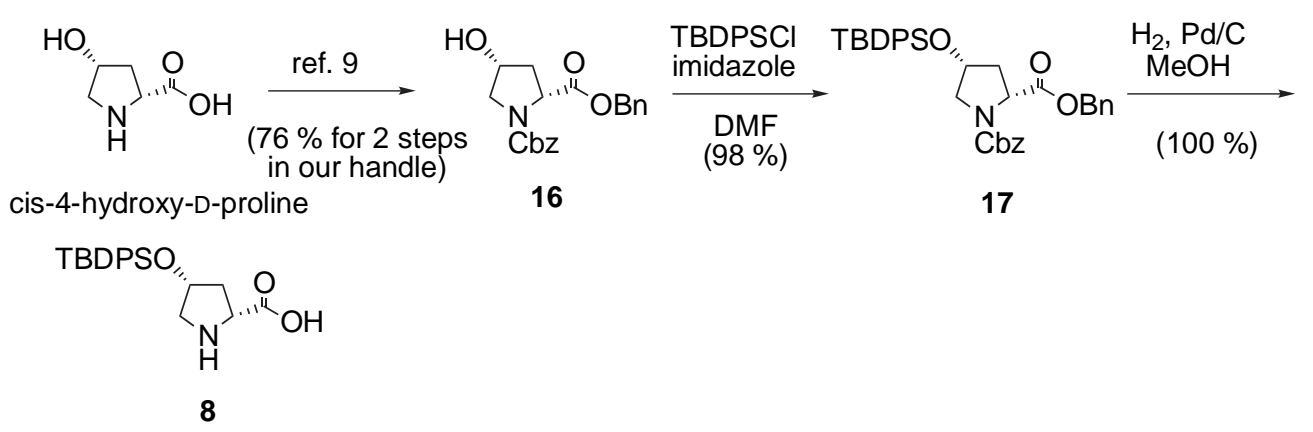

(2R,4R)-4-(tert-butyldiphenylsiloxy)pyrrolidine-1,2-dicarboxylic acid dibenzyl ester [(+)-17]: TBDPSCl (1.54 ml, $5.92 \mathrm{mmol})$ and imidazole (804 mg, $11.8 \mathrm{mmol})$ were added to a solution of alcohol $16(1.75 \mathrm{~g}, 34.8 \mathrm{mmol})$ in DMF $(5.0 \mathrm{ml})$ at room temperature. The reaction mixture was stirred for $24 \mathrm{~h}$ at the same temperature. Then, the reaction mixture was diluted with $\mathrm{Et}_{2} \mathrm{O}$ and the organic solution was washed with $\mathrm{H}_{2} \mathrm{O}$. The aqueous layer was extracted with $\mathrm{Et}_{2} \mathrm{O}$ and the combined organic solution was washed with brine, dried over $\mathrm{MgSO}_{4}$, and concentrated under reduced pressure. The residue was purified by silica gel column chromatography [hexane-AcOEt $(97: 3 \mathrm{v} / \mathrm{v})$ ] to afford silyl ether (+)-17 (2.852 g, $98 \%)$ as a colorless oil.

[]$_{\mathrm{D}}{ }^{28}=+26.5^{\circ}\left(\mathrm{c} 0.84, \mathrm{CHCl}_{3}\right)$; IR (neat): 1798, $1747 \mathrm{~cm}^{-1} ;{ }^{1} \mathrm{H}-\mathrm{NMR}(400 \mathrm{MHz}$, $\left.\mathrm{CDCl}_{3}\right)$ b: $7.62-7.23(\mathrm{~m}, 2 \mathrm{H}), 5.19-4.97\left(\mathrm{~m}\right.$, total $\left.4 \mathrm{H}_{\text {rotamer }}\right), 4.50\left(\mathrm{dd}, 0.5 \mathrm{H}_{\text {rotamer }}, J\right.$ $=8.8,3.4 \mathrm{~Hz}), 4.40\left(\mathrm{dd}, 0.5 \mathrm{H}_{\text {rotamer }}, J=8.8,3.9 \mathrm{~Hz}\right), 4.32(\mathrm{~m}, 1 \mathrm{H}), 3.57(\mathrm{~d}, 1 \mathrm{H}, J=$ $4.4 \mathrm{~Hz}), 3.49(\mathrm{~m}, 1 \mathrm{H}), 2.28-2.12(\mathrm{~m}, 2 \mathrm{H}), 1.03$ and 1.02 (each s, total $9 \mathrm{H}_{\text {rotamer }}$ ); ${ }^{13} \mathrm{C}-\mathrm{NMR}\left(100 \mathrm{MHz}, \mathrm{CDCl}_{3}\right.$ ) (rotamer) b: 171.5, 171.2, 154.7, 154.2, 136.5, 136.3, 135.6, 135.5, 135.4, 133.2, 133.1, 133.0, 129.8, 129.7, 128.39, 128.37, 128.3, 128.2 , 128.1, 128.0, 127.9, 127.80, 127.76, 127.72, 127.7, 127.68, 127.64, 127.6, 71.6, 70.7, 67.03, 66.95, 66.9, 66.8, 58.02, 57.77, 54.9, 54.4, 39.3, 38.4, 26.7, 19.0; MS m/z: $536\left(\mathrm{M}^{+}-\mathrm{C}_{4} \mathrm{H}_{9}\right), 91$ (100\%). HRMS Calcd. $\mathrm{C}_{32} \mathrm{H}_{30} \mathrm{NO}_{5} \mathrm{Si}$ $\left(\mathrm{M}^{+}-\mathrm{C}_{4} \mathrm{H}_{9}\right)$ : 536.1891. Found : 536.1899; Anal. Calcd. for $\mathrm{C}_{36} \mathrm{H}_{39} \mathrm{NO}_{5} \mathrm{Si}$ : C, 72.82 ; $\mathrm{H}, 6.62 ; \mathrm{N}, 2.36$. Found: C, 72.75; H, 6.51; N, 2.40 .

(2R,4R)-4-(tert-butyldiphenylsilyloxy)-D-proline [(+)-8]: 10\% (w/w) Pd/C (255 $\mathrm{mg}$ ) was added to a solution of ester-carbamate $(+)-17(2.550 \mathrm{~g}, 4.29 \mathrm{mmol})$ in $\mathrm{MeOH}(23.3 \mathrm{ml})$ and the mixture was stirred under atmospheric pressure of $\mathrm{H}_{2}$ 
for $48 \mathrm{~h}$ at room temperature. Then, the reaction mixture was filtered through a Celite pad, and concentrated under reduced pressure to afford amino acid (+)-8 $(1.583 \mathrm{~g}, 100 \%)$ as a colorless solid.

$\mathrm{mp} 137-138.5^{\circ} \mathrm{C}$; []$_{\mathrm{D}}{ }^{27}=+3.85^{\circ}\left(\mathrm{c} 0.7, \mathrm{CH}_{3} \mathrm{OH}\right.$ ); IR (nujol): $3404,1714 \mathrm{~cm}^{-1}$. ${ }^{1} \mathrm{H}-\mathrm{NMR}\left(400 \mathrm{MHz}, \mathrm{CD}_{3} \mathrm{OD}\right)$ b: 7.67-7.63 (m, 4H), 7.48-7.39 (m, 6H), 4.50 (br.s, $1 \mathrm{H}), 4.24(\mathrm{~m}, 1 \mathrm{H}), 3,34(\mathrm{~d}, 1 \mathrm{H}, J=12.2 \mathrm{~Hz}), 3.18(\mathrm{q}, 1 \mathrm{H}, J=12.2,3.7 \mathrm{~Hz}), 2.39$ $(\mathrm{m}, 1 \mathrm{H}), 2.29(\mathrm{~m}, 1 \mathrm{H}), 1.05(\mathrm{~s}, 9 \mathrm{H}) ;{ }^{13} \mathrm{C}-\mathrm{NMR}\left(100 \mathrm{MHz}, \mathrm{CD}_{3} \mathrm{OD}\right)$ b: 172.7 , 136.93, 136.87, 134.1, 133.9, 131.29, 131.27, 129.1, 129.0, 72.9, 60.4, 54.9, 39.4, 27.2, 19.8; MS m/z : $312\left(\mathrm{M}^{+}-\mathrm{C}_{4} \mathrm{H}_{9}\right), 234$ (100\%). HRMS Calcd. $\mathrm{C}_{17} \mathrm{H}_{18} \mathrm{NO}_{3} \mathrm{Si}\left(\mathrm{M}^{+}-\mathrm{C}_{4} \mathrm{H}_{9}\right): 312.1055$. Found : 312.1022 .

tetrabutylammonium L-prolinate $\quad(9): 10.7 \% \quad(w / v)$ tetrabutylammonium hydroxide in $\mathrm{MeOH}(4.73 \mathrm{ml}, 1.95 \mathrm{mmol})$ was added to a stirred solution of Lproline (230 mg, $2.00 \mathrm{mmol})$ in $\mathrm{MeOH}(2.0 \mathrm{ml})$ at room temperature and stirring was continued for $30 \mathrm{~min}$ at the same temperature. Then, the mixture was concentrated in vacuo to give ammonium salt $\mathbf{9}$ as a colorless oil.

tetrabutylammonium (4R)-4-(tert-butyldiphenylsilyloxy)-L-prolinate (10): $10.7 \%(\mathrm{w} / \mathrm{v})$ (concentration was determined by neutralization titration) tetrabutylammonium hydroxide in $\mathrm{MeOH}(1.20 \mathrm{ml}, 0.496 \mathrm{mmol})$ was added to a stirred solution of amino acid (-)-7 (200 mg, $0.541 \mathrm{mmol})$ in $\mathrm{MeOH}(2.2 \mathrm{ml})$ at room temperature and stirring was continued for $30 \mathrm{~min}$ at the same temperature. Then, the mixture was concentrated in vacuo to give ammonium salt 10 (320 mg, $100 \%)$ as a colorless oil.

tetrabutylammonium (4R)-4-(tert-butyldiphenylsilyloxy)-D-prolinate (11): $10.0 \%(\mathrm{w} / \mathrm{v})$ (concentration was determined by neutralization titration) tetrabutylammonium hydroxide in $\mathrm{MeOH}(0.63 \mathrm{ml}, 0.243 \mathrm{mmol})$ was added to a stirred solution of amino acid (+)-8 $(100 \mathrm{mg}, 0.271 \mathrm{mmol})$ in $\mathrm{MeOH}(2.0 \mathrm{ml})$ at room temperature and stirring was continued for $30 \mathrm{~min}$ at the same temperature. Then, the mixture was concentrated in vacuo to give ammonium salt 11 (159 mg, $100 \%)$. 
Tetrabutylammonium L-aspartate (12): $10.7 \%(\mathrm{w} / \mathrm{v})$ tetrabutylammonium hydroxide in $\mathrm{MeOH}(0.48 \mathrm{ml}, 0.20 \mathrm{mmol})$ was added to a stirred mixture of Laspartic acid (26 mg, $0.20 \mathrm{mmol})$ in $\mathrm{MeOH}(0.2 \mathrm{ml})$ at room temperature and stirring was continued for $30 \mathrm{~min}$ at the same temperature. Then, the mixture was concentrated in vacuo to give ammonium salt 12.

(5) Preparation of _-branched ketoaldehyde 1c

1c was synthesized according to the reported procedure ${ }^{3}$ as shown in the following scheme.

\section{Scheme 4}

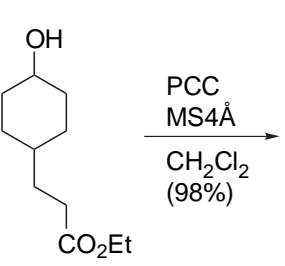<smiles>CCOC(=O)CCC1CCC(=O)CC1</smiles>

18

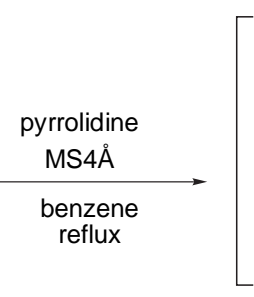

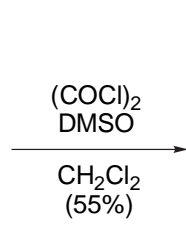

21

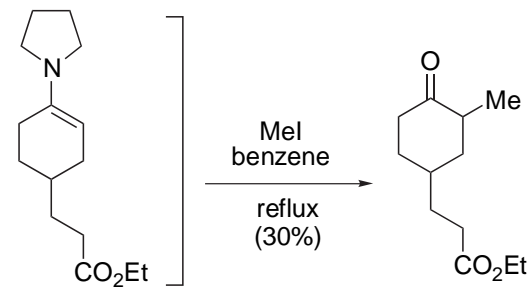

19

20

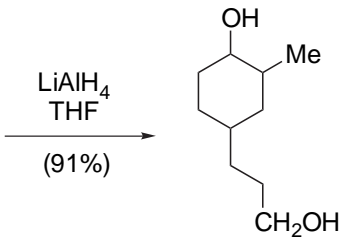<smiles>CC1CC(CCC=O)CCC1=O</smiles>

$1 \mathrm{c}$

3-(4-oxocyclohexyl)propionic acid ethyl ester (18): A solution of 3-(4hydroxycyclohexyl)propionic acid ethyl ester (1.824 g, $9.11 \mathrm{mmol})$ in $\mathrm{CH}_{2} \mathrm{Cl}_{2}(9.0$ $\mathrm{ml}$ ) was added dropwisely to a mixture of PCC (3.93 $\mathrm{g}, 18.2 \mathrm{mmol})$ and molecular sieves $4 \AA(9.7 \mathrm{~g})$ in $\mathrm{CH}_{2} \mathrm{Cl}_{2}(46.0 \mathrm{ml})$ at $0{ }^{\circ} \mathrm{C}$ and the mixture was stirred for $1 \mathrm{~h}$ at room temperature. The reaction mixture was filtered through a Celite pad and concentrated under reduced pressure. The crude mixture was purified by silica gel column chromatography [hexane-AcOEt $(17: 3 \mathrm{v} / \mathrm{v})$ ] to afford ketoester 18 (1.763 g, $98 \%)$ as a colorless oil.

IR (neat): $1735,1714,1235 \mathrm{~cm}^{-1} .{ }^{1} \mathrm{H}-\mathrm{NMR}\left(400 \mathrm{MHz}, \mathrm{CDCl}_{3}\right)$ b: 4.08 (t, $2 \mathrm{H}, J=$ $6.7 \mathrm{~Hz}), 2.42-2.28(\mathrm{~m}, 4 \mathrm{H}), 2.09-2.03(\mathrm{~m}, 5 \mathrm{H}), 1.79-1.66(\mathrm{~m}, 3 \mathrm{H}), 1.46-1.35(\mathrm{~m}$, 
$4 \mathrm{H}) ;{ }^{13} \mathrm{C}-\mathrm{NMR}\left(100 \mathrm{MHz}, \mathrm{CDCl}_{3}\right.$ ) b: 211.7, 171.0, 64.5, 40.7, 35.7, 32.6, 31.8, 26.4, 21.0; MS m/z : $198\left(M^{+}\right), 43(100 \%)$. HRMS Calcd. $\mathrm{C}_{11} \mathrm{H}_{18} \mathrm{O}_{3}: 198.1255$. Found : 198.1225.

3-(3-methyl-4-oxocyclohexyl)propionic acid ethyl ester (20): Pyrrolidine (1.02 $\mathrm{ml}, 12.2 \mathrm{mmol})$ was added to a mixture of ketoester $18(1.72 \mathrm{~g}, 8.68 \mathrm{mmol})$ and molecular sieves $4 \AA(9.7 \mathrm{~g})$ in benzene $(26.3 \mathrm{ml})$ and the mixture was refluxed with removal of water using a Dean-Stark apparatus for $6 \mathrm{~h}$. After cooling, the solvent and excess pyrrolidine were removed in vacuo to give a cude product 19. Benzene $(14.0 \mathrm{ml})$ and iodomethane $(0.580 \mathrm{ml}, 9.32 \mathrm{ml})$ were added to this and the mixture was refluxed for $15 \mathrm{~h}$. After cooling to room temperature, $\mathrm{H}_{2} \mathrm{O}(6.5 \mathrm{ml})$ and silica gel $(650 \mathrm{mg})$ were added and the mixture was stirred for $3 \mathrm{~h}$. Then, this mixture was poured into $\mathrm{H}_{2} \mathrm{O}$ and extracted with $\mathrm{Et}_{2} \mathrm{O}$ several times. The combined organic solution was washed with brine, dried over $\mathrm{MgSO}_{4}$, and concentrated under reduced pressure. The residue was purified by silica gel column chromatography [hexane-AcOEt (19:1-9:1 v/v)] to afford ester 20 (562 mg, $30 \%$ ) as a colorless oil and recover starting ketoester 18 (600 mg, $35 \%$ ).

IR (neat): 1738, 1711, $1247 \mathrm{~cm}^{-1} .{ }^{1} \mathrm{H}-\mathrm{NMR}\left(400 \mathrm{MHz}, \mathrm{CDCl}_{3}\right)$ b: 4.10 (t, $2 \mathrm{H}, J=$ $6.7 \mathrm{~Hz}), 2.52(\mathrm{~m}, 1 \mathrm{H}), 2.36(\mathrm{~m}, 2 \mathrm{H}), 2.06(\mathrm{~s}, 3 \mathrm{H}), 1.98-1.86(\mathrm{~m}, 2 \mathrm{H}), 1.81-1.63(\mathrm{~m}$, $5 \mathrm{H}$ ), $1.50(\mathrm{~m}, 2 \mathrm{H}), 1.10$ and 1.01 (each d, total $3 \mathrm{H}, J=6.8$ and $6.6 \mathrm{~Hz}$ ); $\mathrm{MS} \mathrm{m} / \mathrm{z}$ : $212\left(\mathrm{M}^{+}\right), 43(100 \%)$. HRMS Calcd. $\mathrm{C}_{12} \mathrm{H}_{20} \mathrm{O}_{3}: 212.1411$. Found : 212.1404 .

4-(3-hydroxypropyl)-2-methylcyclohexanol (21): A solution of ketoester 20 (462 $\mathrm{mg}, 2.18 \mathrm{mmol})$ in THF $(7.5 \mathrm{ml})$ was dropped to a stirred suspention of $\mathrm{LiAlH}_{4}(207 \mathrm{mg}, 5.44 \mathrm{mmol})$ in THF $(8.6 \mathrm{ml})$ at $0{ }^{\circ} \mathrm{C}$ and the mixture was stirred for $12 \mathrm{~h}$ at room temperature. Then, $\mathrm{H}_{2} \mathrm{O}(5.4 \mathrm{ml})$ and $15 \%$ aqueous $\mathrm{NaOH}(5.4$ $\mathrm{ml}$ ) was added to the reaction mixture at $0{ }^{\circ} \mathrm{C}$, and stirring was continued for 10 min at the same temperature. Additional $\mathrm{H}_{2} \mathrm{O}(16.2 \mathrm{ml})$ was added to the reaction mixture and further stirring was continued for $30 \mathrm{~min}$ at $0{ }^{\circ} \mathrm{C}$. After addition of $\mathrm{MgSO}_{4}$, the mixture was filtered through a Celite pad and concentrated under reduced pressure. The residue was purified by silica gel column chromatography [hexane-AcOEt (1:1 v/v)] to afford diol 21 (341 mg, $91 \%$ ) as a colorless oil. 
IR (neat): $3348 \mathrm{~cm}^{-1} ;{ }^{1} \mathrm{H}-\mathrm{NMR}\left(400 \mathrm{MHz}, \mathrm{CDCl}_{3}\right)$ b: 3.71-3.02 (m, total $\left.5 \mathrm{H}\right)$, 2.030.64 (m, total $15 \mathrm{H})$; MS m/z : $172\left(\mathrm{M}^{+}\right), 95$ (100\%). HRMS Calcd. $\mathrm{C}_{10} \mathrm{H}_{20} \mathrm{O}_{2}$ : 172.1462. Found : 172.1437 .

3-(3-methyl-4-oxocyclohexyl)propionaldehyde (1c): A solution of diol 21 (158 $\mathrm{mg}, 0.917 \mathrm{mmol})$ in $\mathrm{CH}_{2} \mathrm{Cl}_{2}(1.3 \mathrm{ml})$ was added to a stirred suspension of PCC (858 $\mathrm{mg}, 3.98 \mathrm{mmol})$ and molecular sieves $4 \AA$ (1.30 g) in $\mathrm{CH}_{2} \mathrm{Cl}_{2}(6.7 \mathrm{ml})$ at $0{ }^{\circ} \mathrm{C}$ and the mixture was stirred for $1 \mathrm{~h}$ at room temperature. Then, Florisil ${ }^{\circledR}$ was added to the reaction mixture and stirring was continued for $10 \mathrm{~min}$. After dilution with $\mathrm{Et}_{2} \mathrm{O}$, the mixture was filtered through Florisil $^{\circledR}$ and concentrated under reduced pressure. The residue was purified by silica gel column chromatography [hexane-AcOEt $(17: 3 \mathrm{v} / \mathrm{v})$ ] to afford ketoaldehyde 1c (85 mg, $55 \%$ ) as a colorless oil.

IR (neat): $1707 \mathrm{~cm}^{-1} ;{ }^{1} \mathrm{H}-\mathrm{NMR}\left(400 \mathrm{MHz}, \mathrm{CDCl}_{3}\right.$ ) b: 9.82 and 9.80 (each t, total $1 \mathrm{H}$, each $J=1.5 \mathrm{~Hz}), 2.56-2.34(\mathrm{~m}$, total $5 \mathrm{H}), 2.08-1.62(\mathrm{~m}$, total $7 \mathrm{H}), 1.10$ and 1.01 (each t, total $3 \mathrm{H}, J=7.1,6.6 \mathrm{~Hz}$ ) ; MS m/z: $168\left(\mathrm{M}^{+}\right), 55(100 \%)$. HRMS Calcd. $\mathrm{C}_{10} \mathrm{H}_{16} \mathrm{O}_{2}:$ 168.1149. Found : 168.1133.

\section{References}

(1) (a) Frigerio, M.; Santagostino, M.; Sputore, S. J. Org. Chem. 1999, 64, 4537.(b) Nicolaou, K. C.; Zhong, Y.-L.; Baran, P. S. J. Am. Chem. Soc. 2000, 122, 7596. (c) Nicolaou, K. C.; Montagnon, T.; Baran, P. S. Angew. Chem. Int. Ed. 2002, 41, 993.

(2) (a) Dess, D. B.; Martin, J. C. J. Org. Chem. 1983, 48, 4156. (b) Ireland, R. E.; Liu, L. J. Org. Chem. 1993, 58, 2899.

(3) Mori, K.; Takayama, S.; Kido, M. Bioorg. Med. Chem. 1994, 2, 395.

(4) Dale, J. A.; Mosher, H. S. J. Am. Chem. Soc. 1973, 95, 512.

(5) Nagata, H.; Miyazawa, N.; Ogasawara, K. Synthesis 2000, 2013.

(6) Elliott, M. L.; Urban, F. J. J. Org. Chem. 1985, 50, 1752.

(7) Tamaki, M.; Han, G.; Hruby, V. J. J. Org. Chem. 2001, 66, 1038.

(8) Ohtake, H.; Imada, Y.; Murahashi, S. Bull. Chem. Soc. Jpn. 1999, 72, 2737.

(9) (a) Remuzon, P.; Massoudi, M.; Bouzard, D.; Jacquet, J.-P. Heterocycles 1992, 34, 679. (b) Rumuzon, P.; Bouzard, D.; Guiol, C.; Jacquet, J.-P. J. Med. 
Chem. 1992, 35, 2898. 


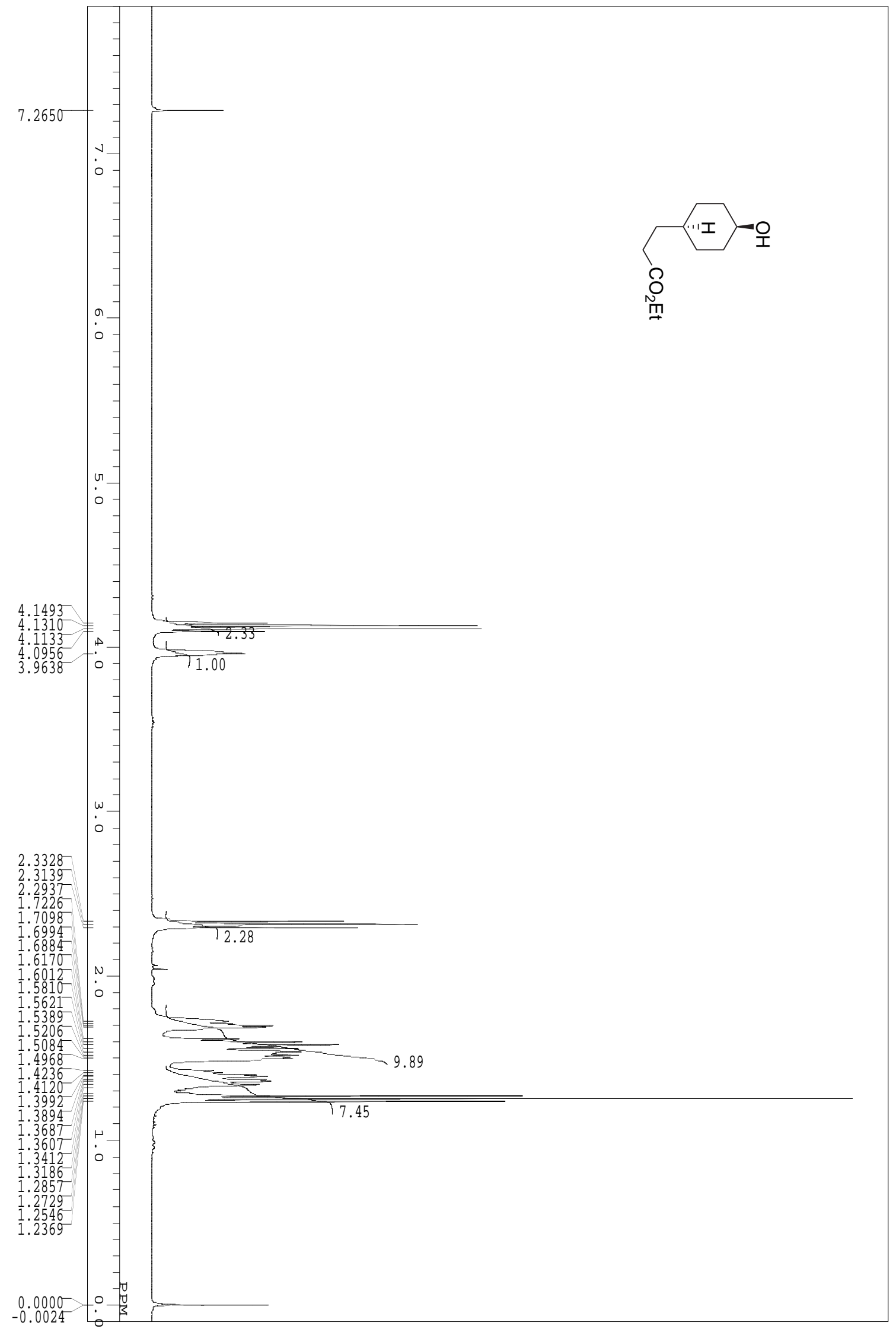

S-18 


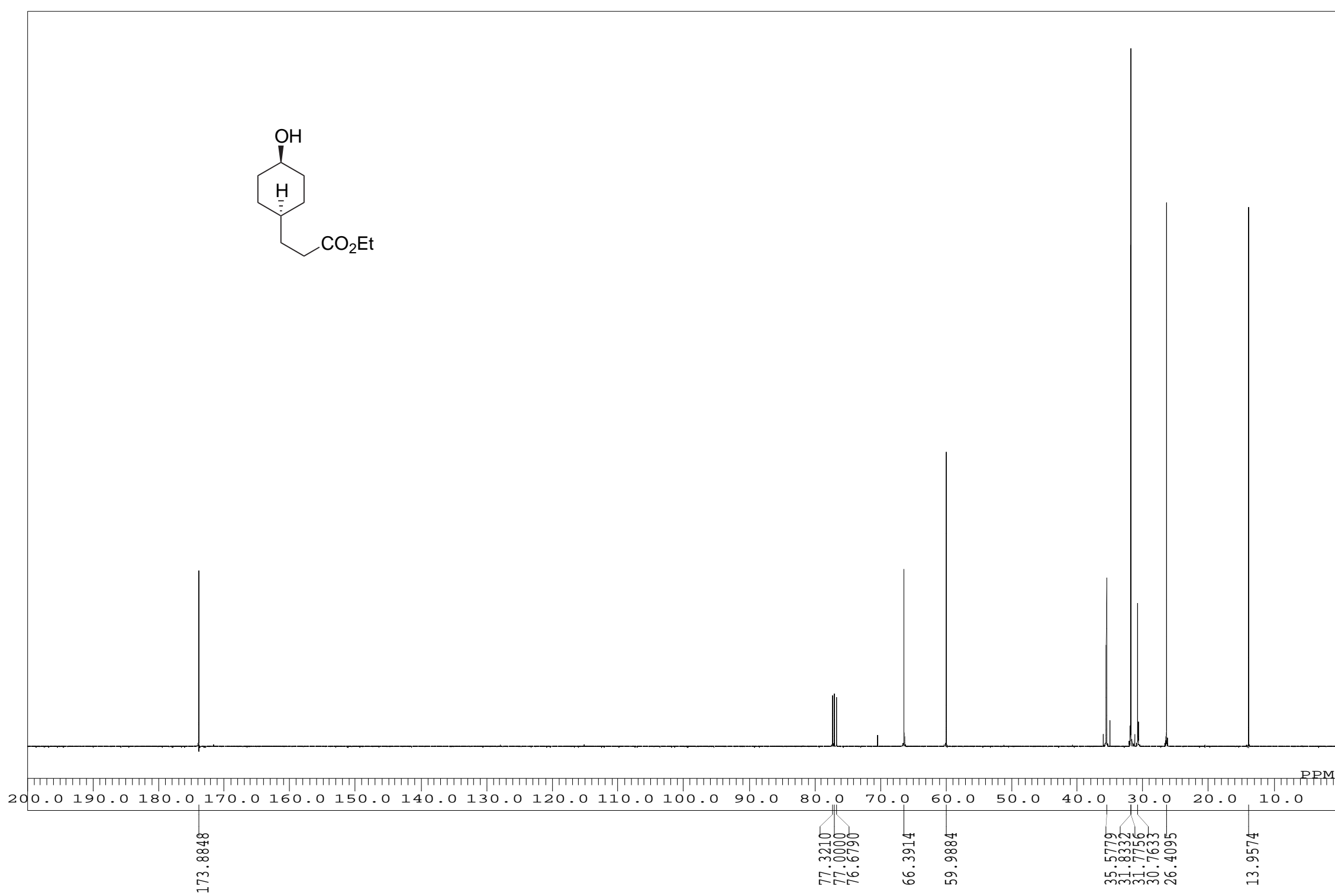




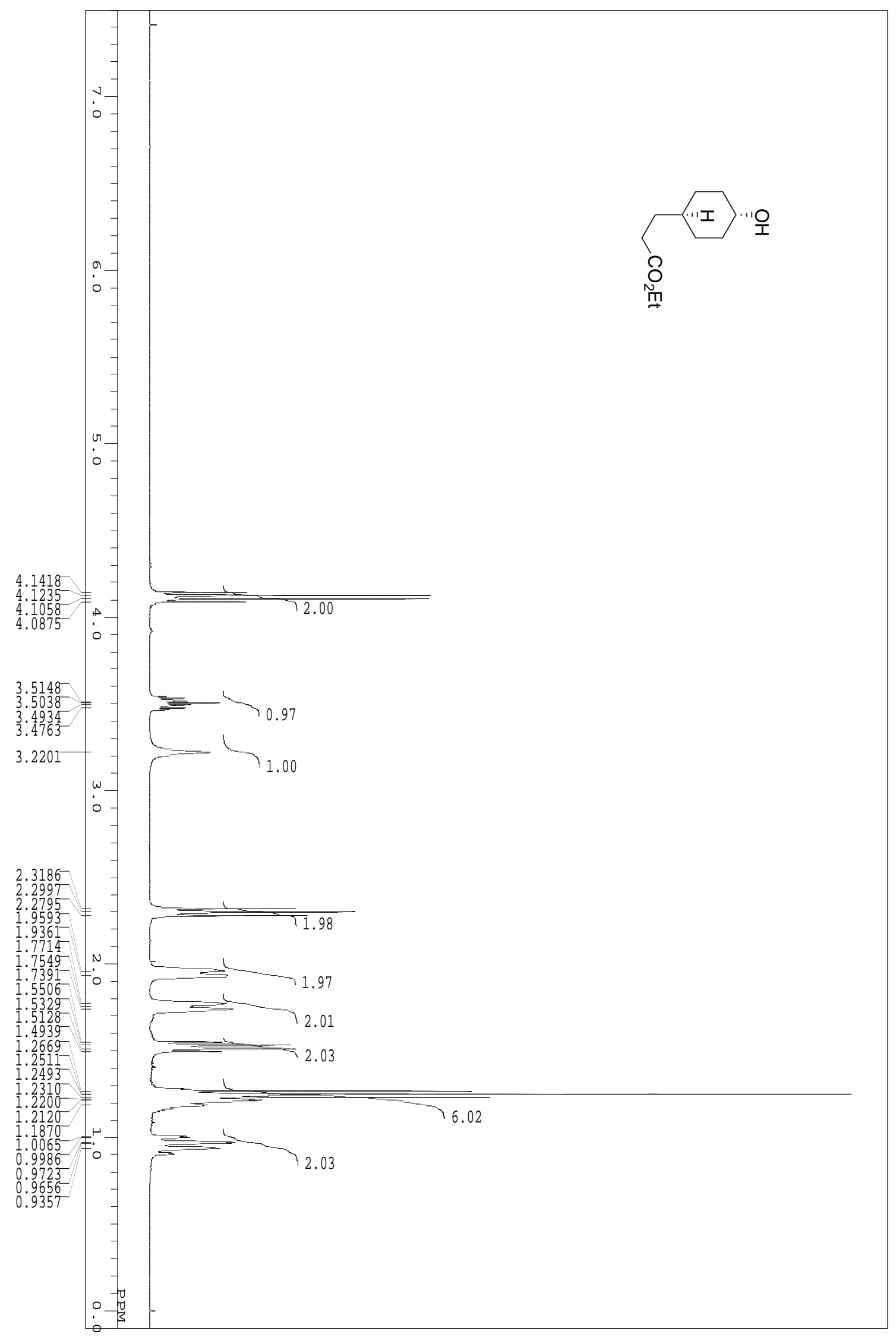




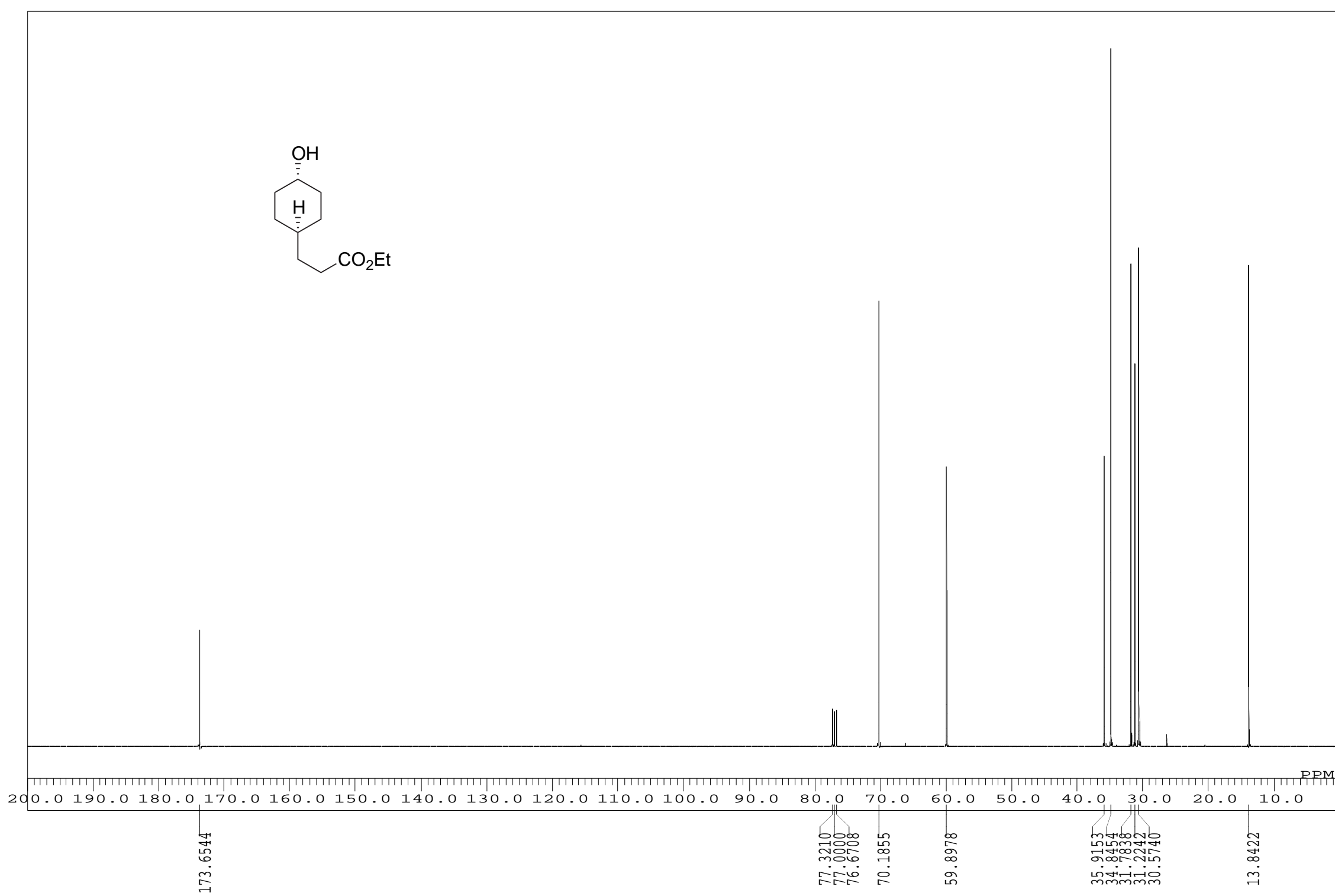




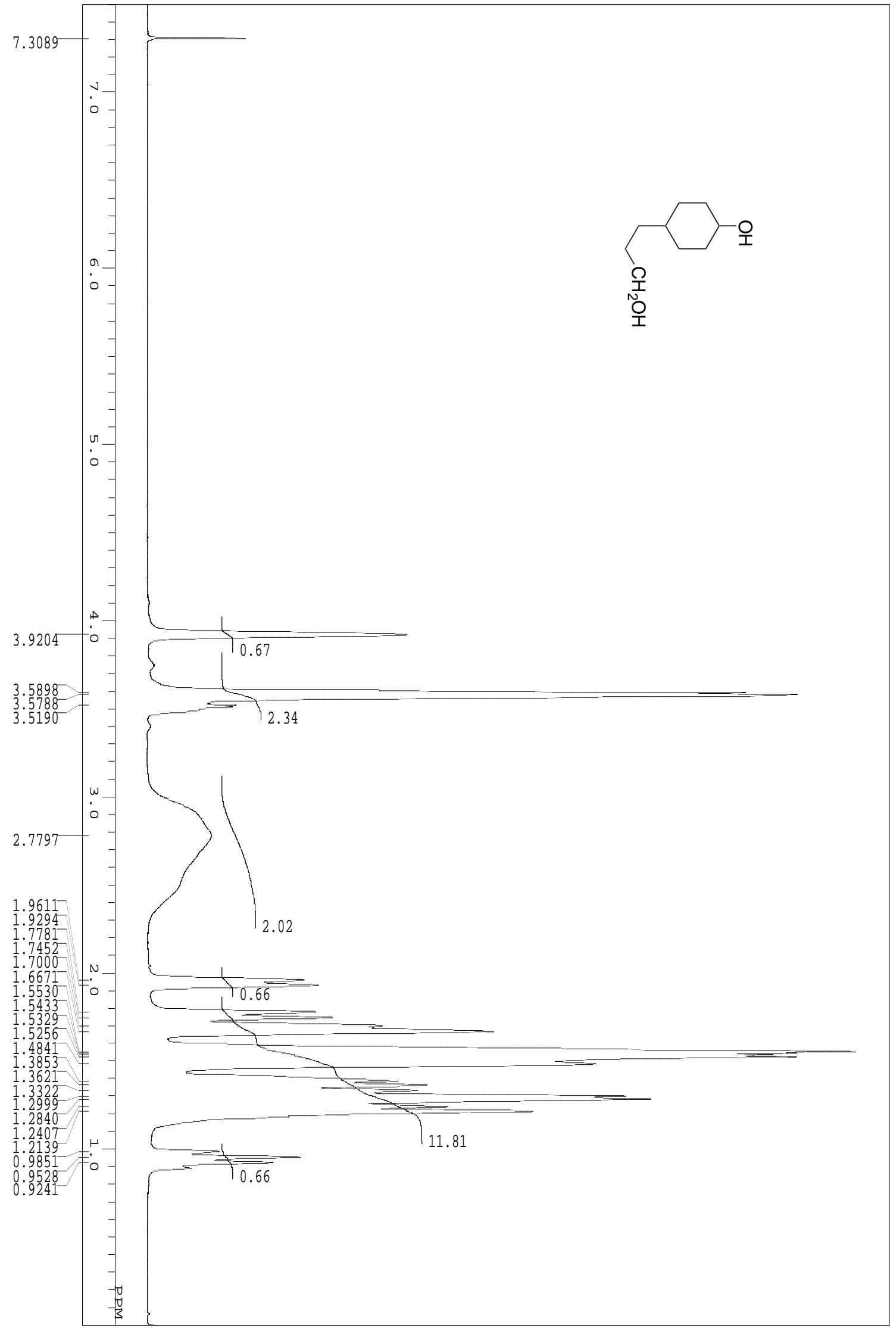




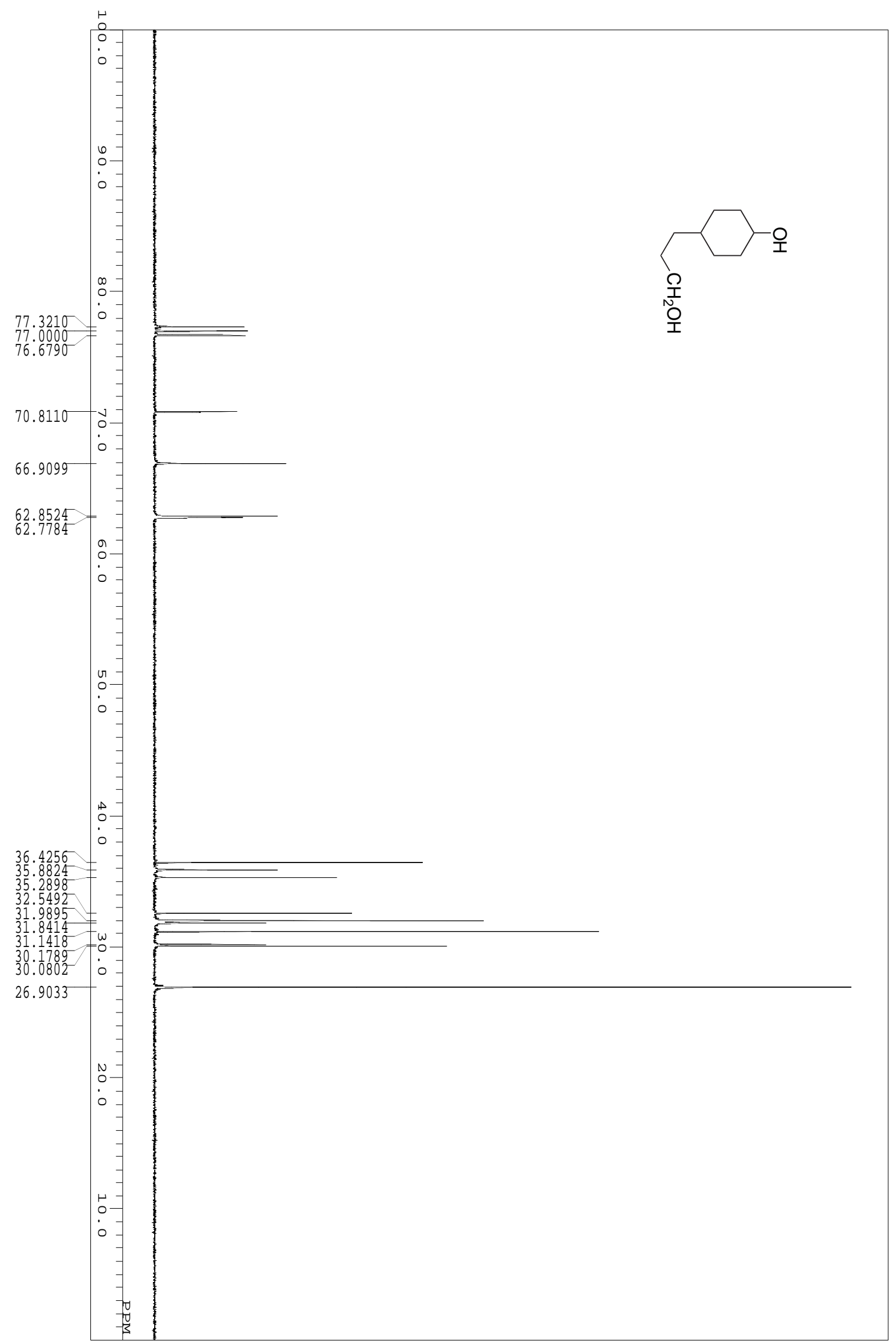

S-23 


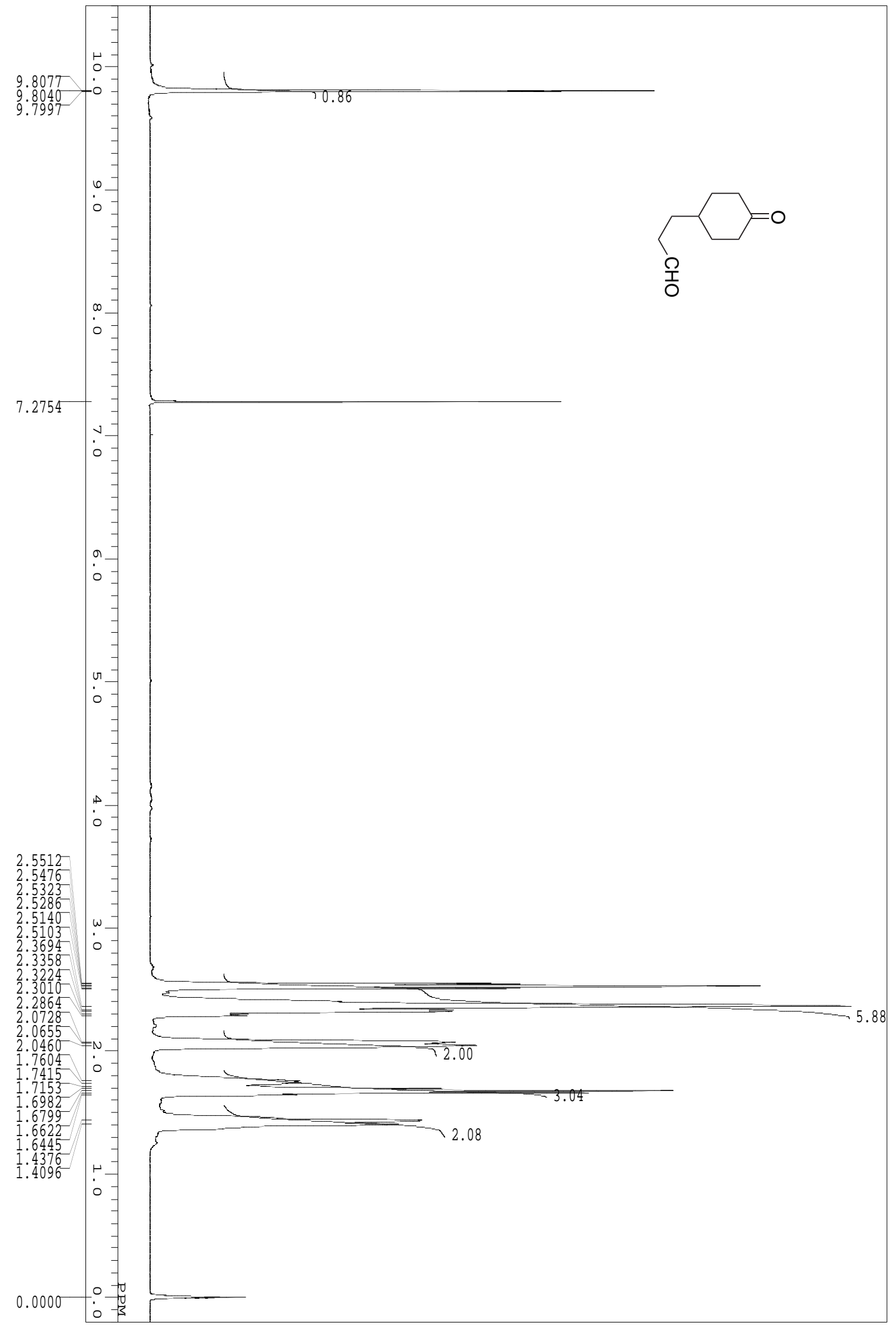

S-24 


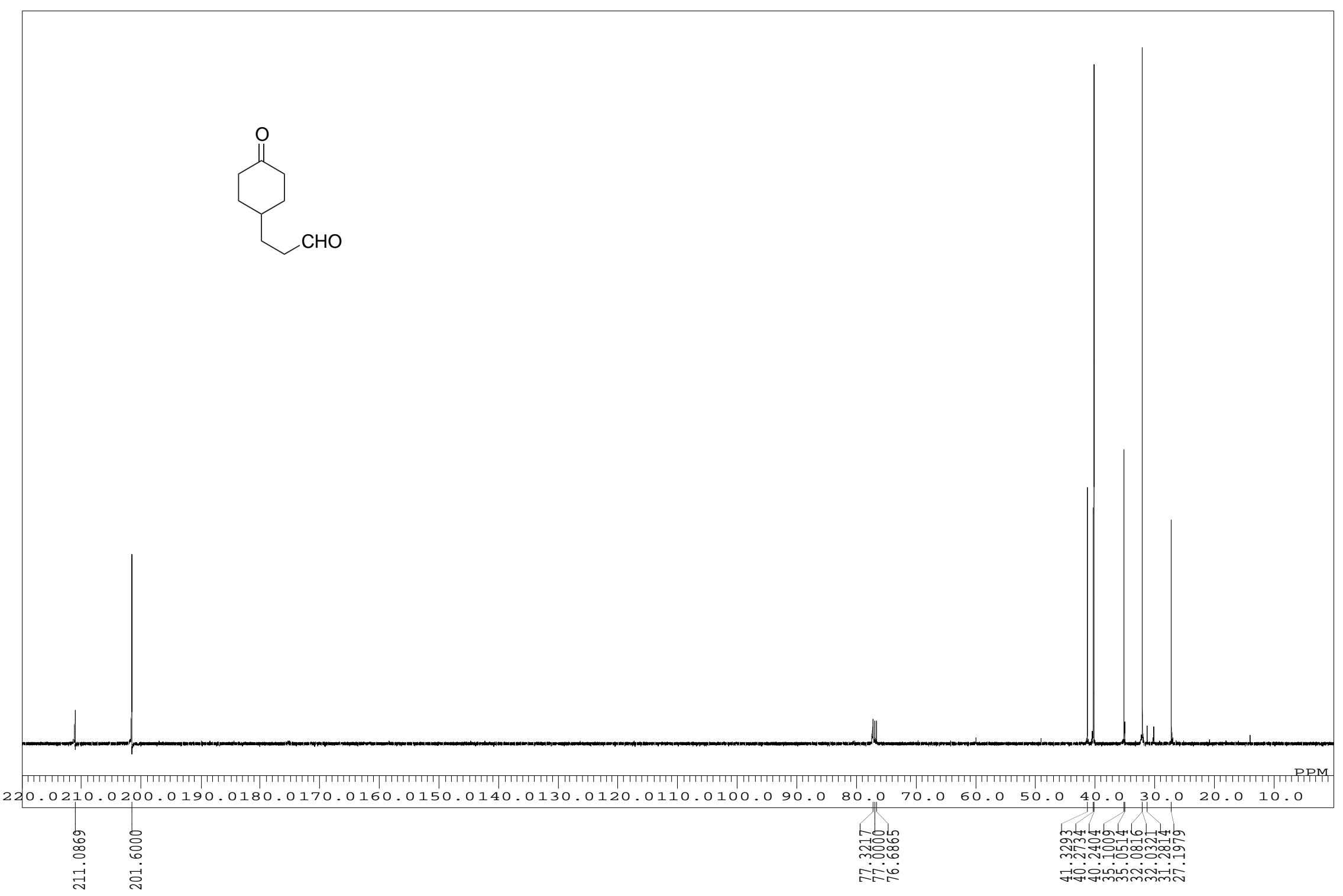

ஸे 


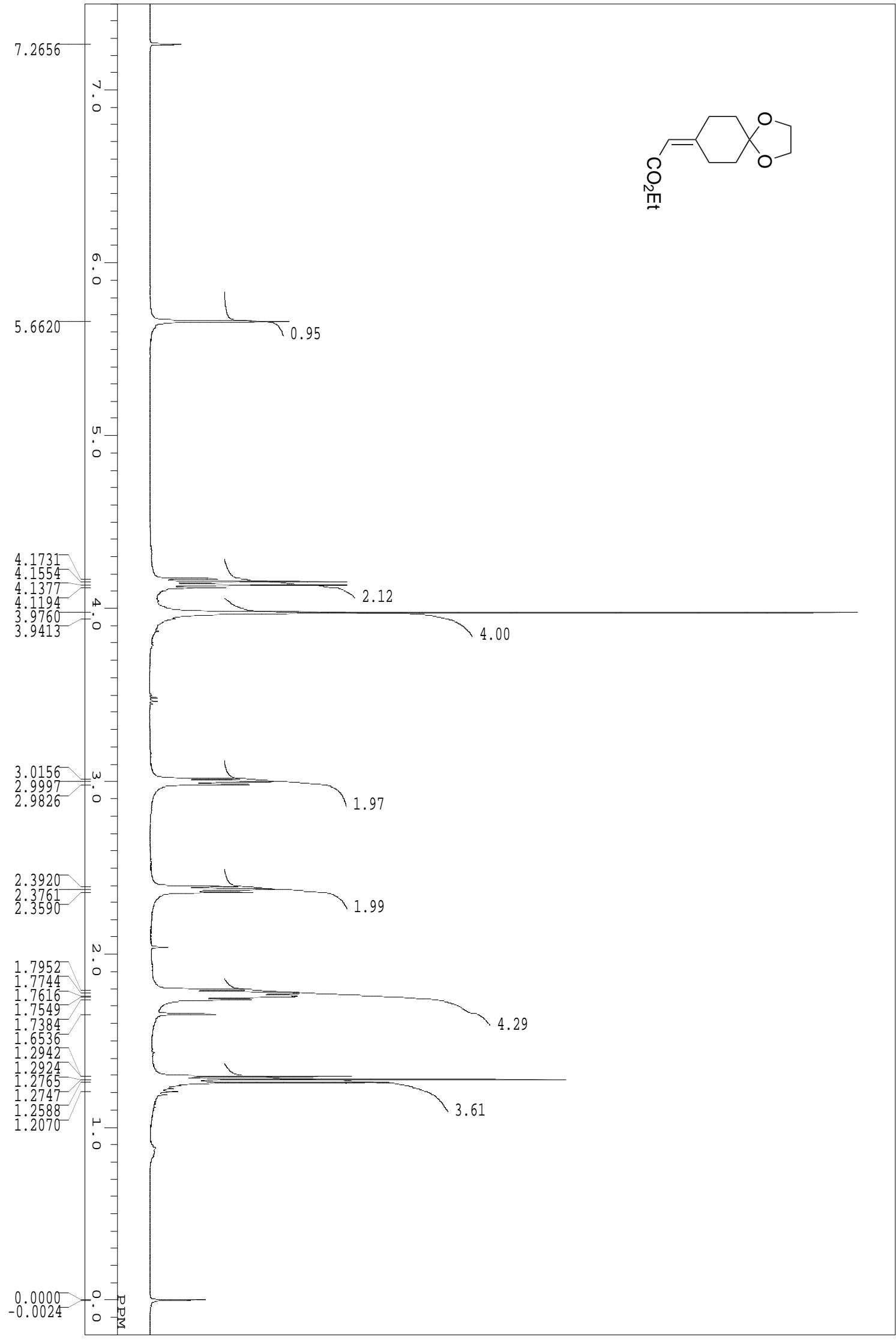




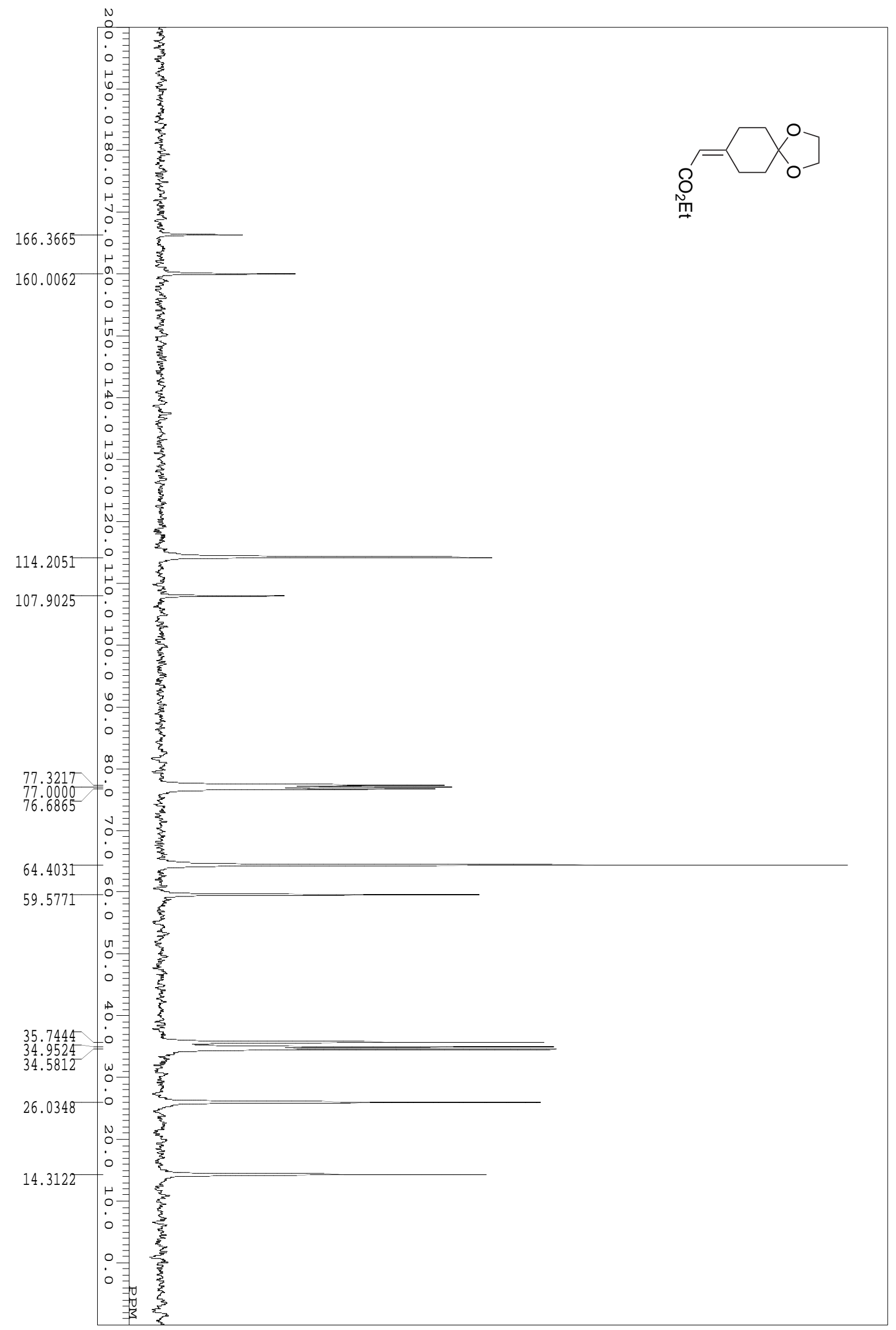




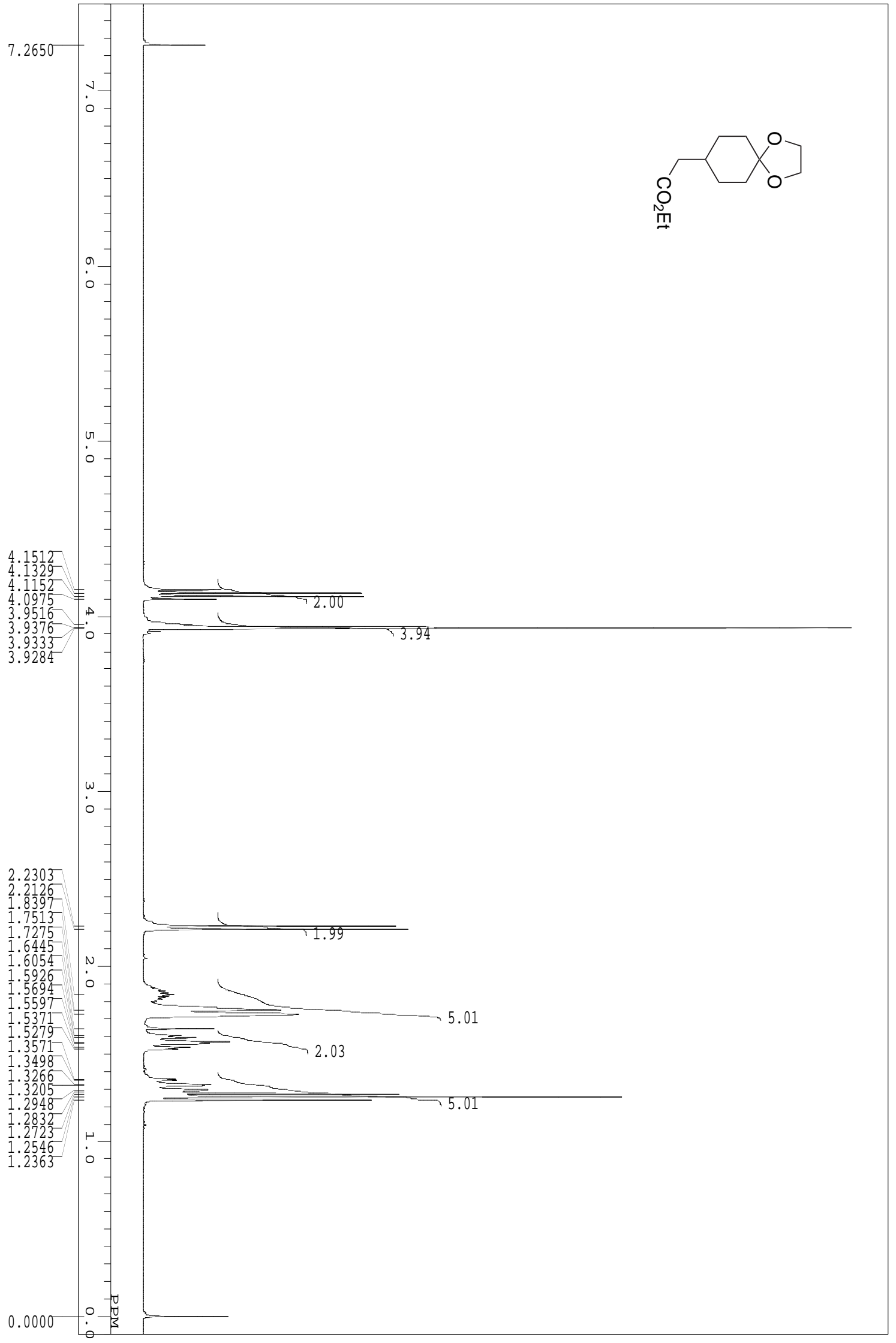

S-28 


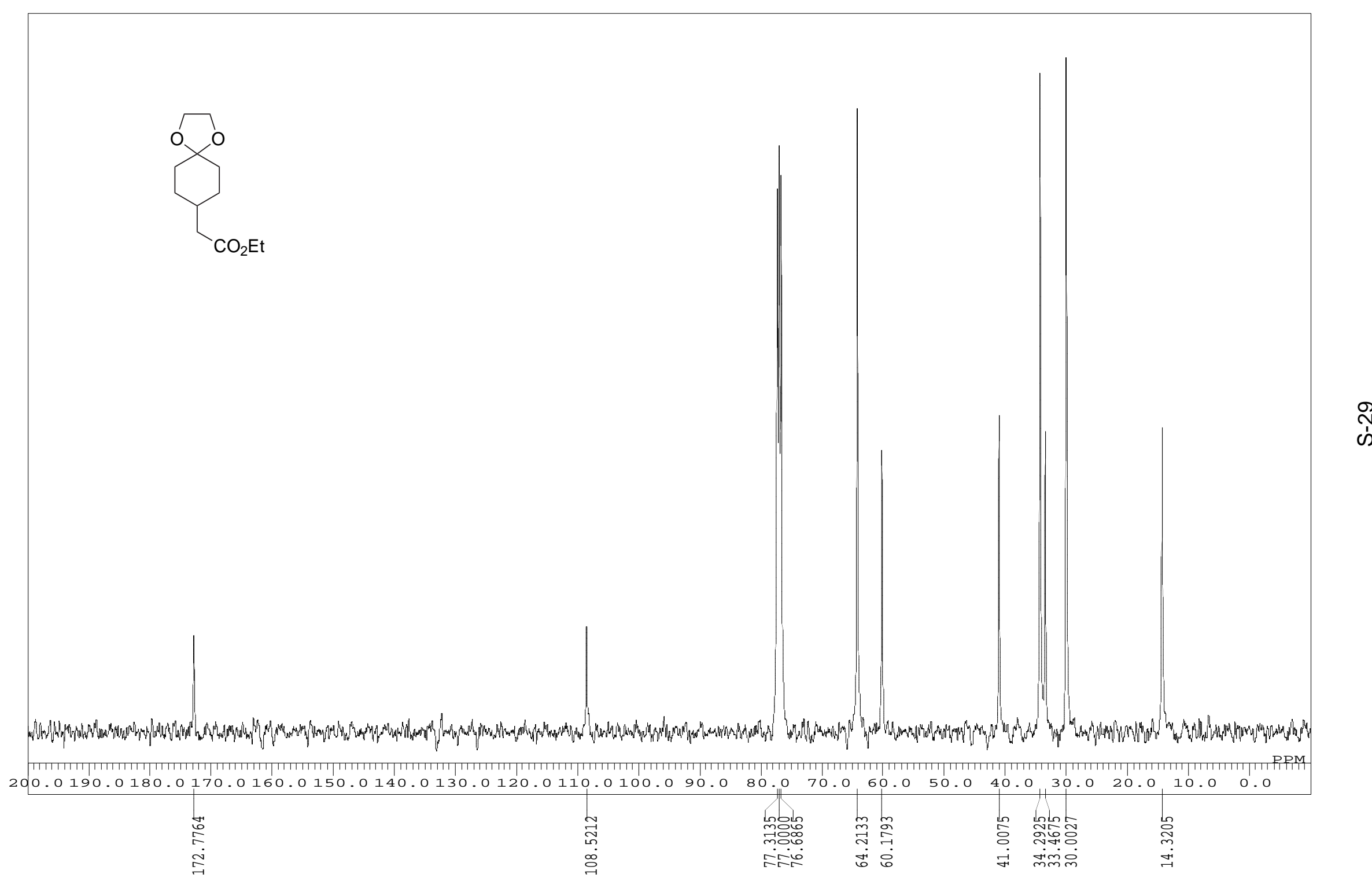

ì 


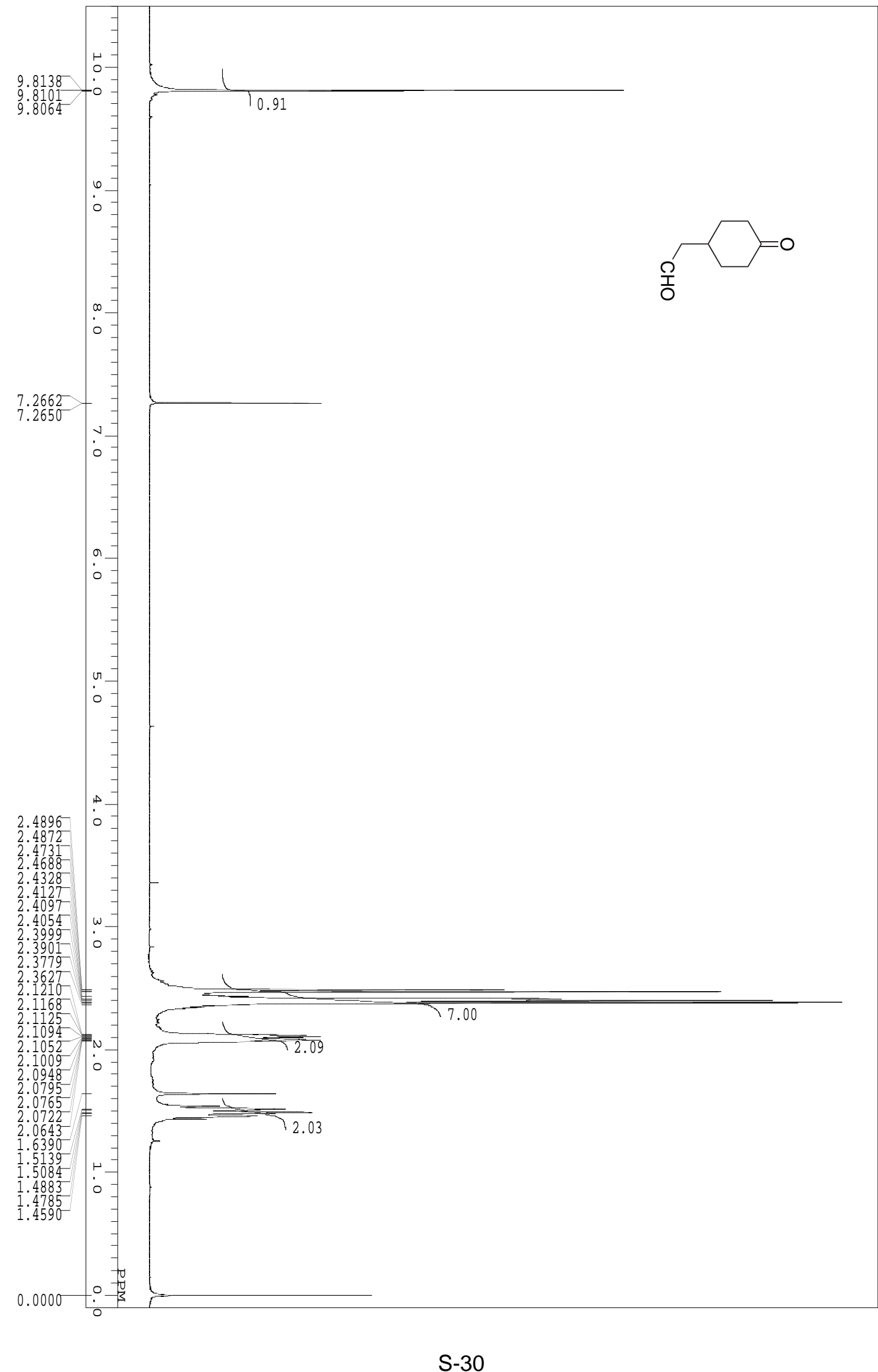




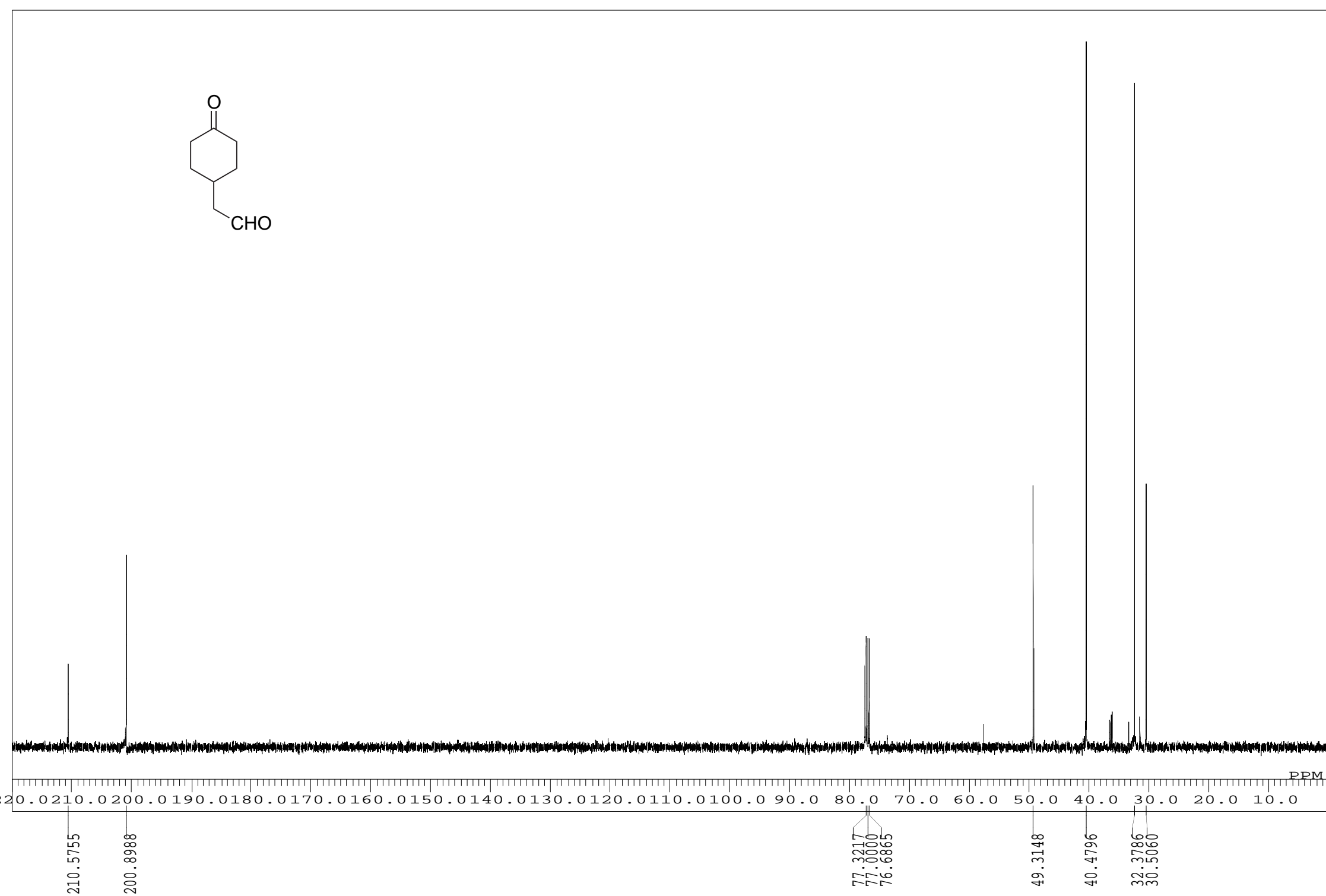




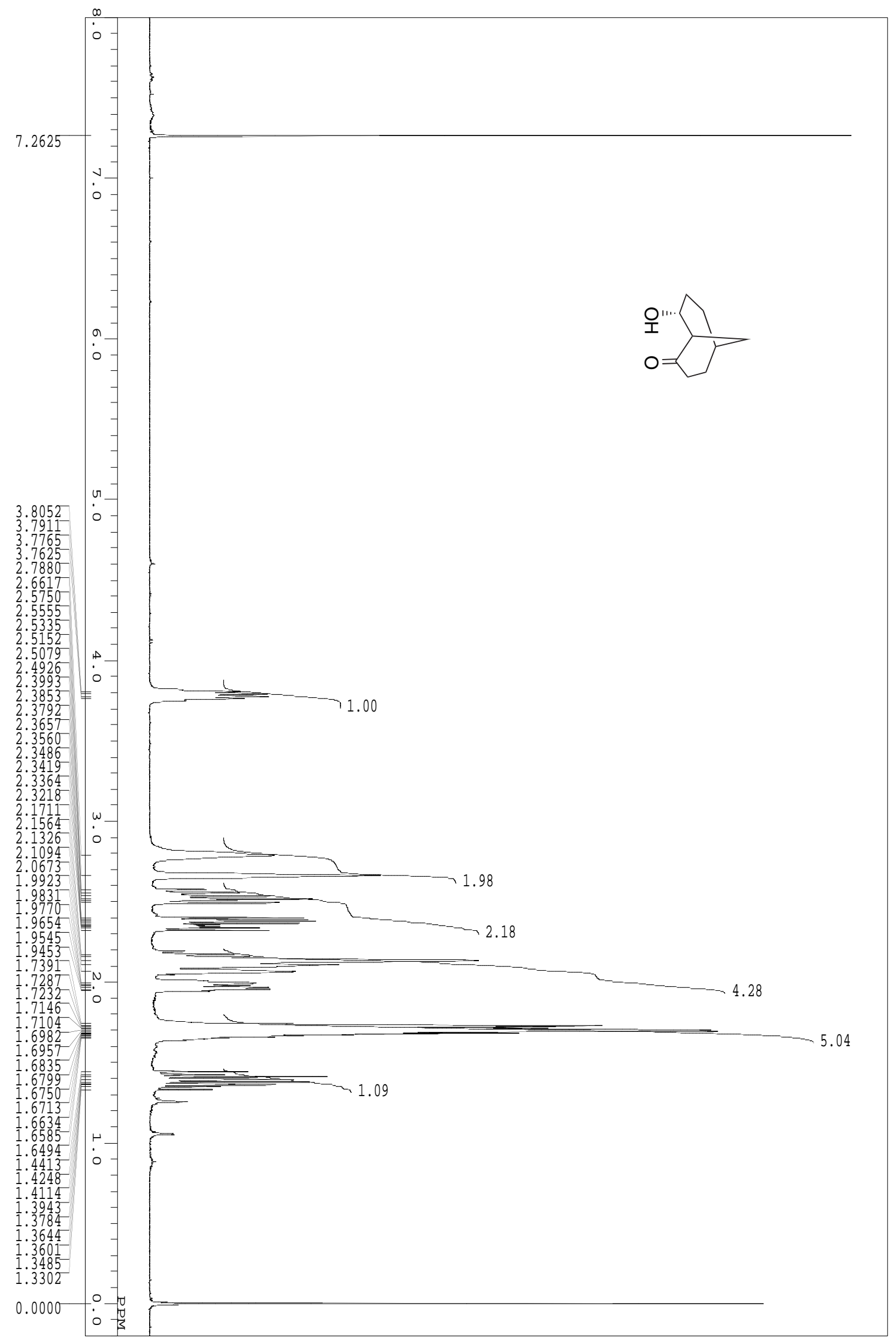

S-32 


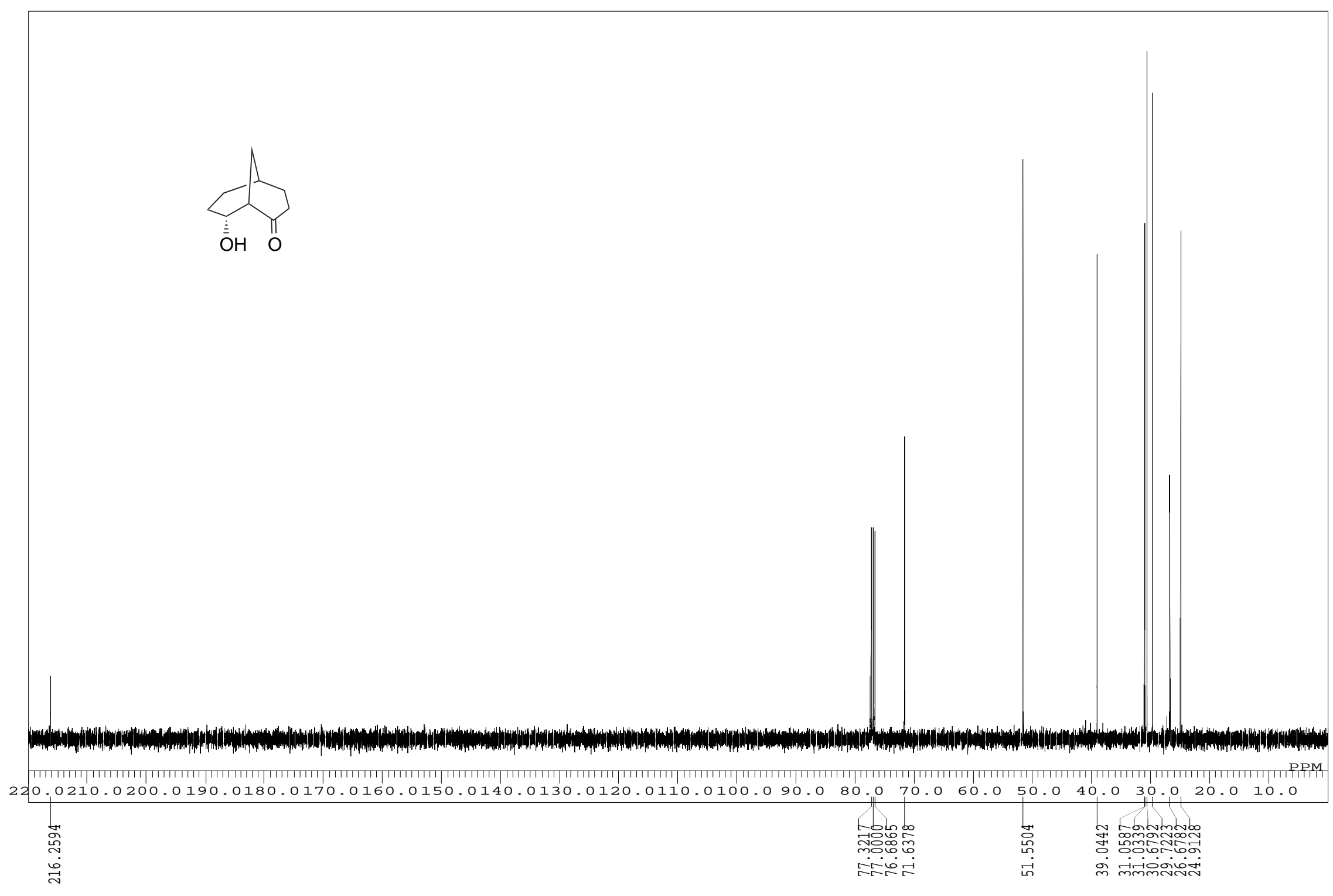




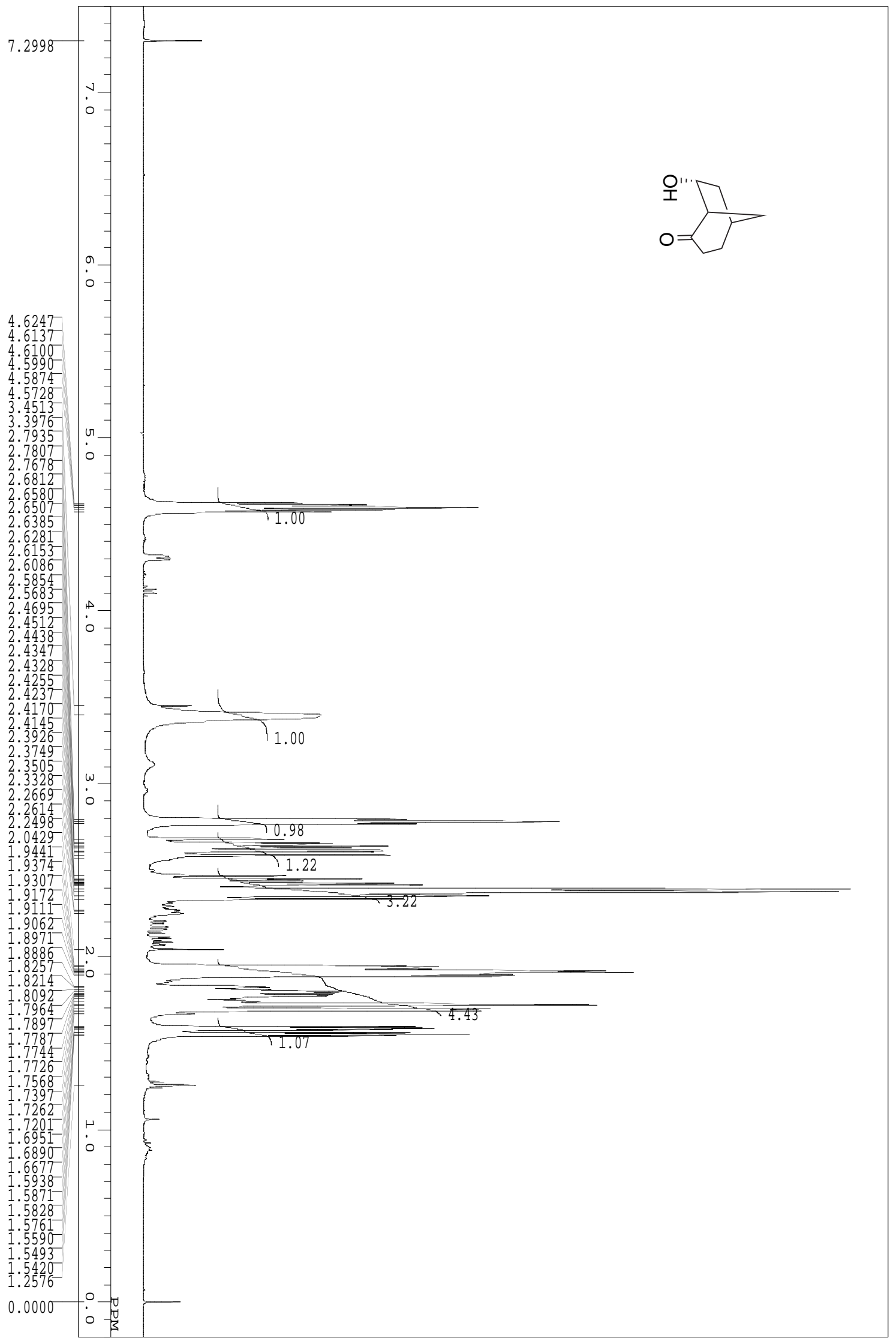




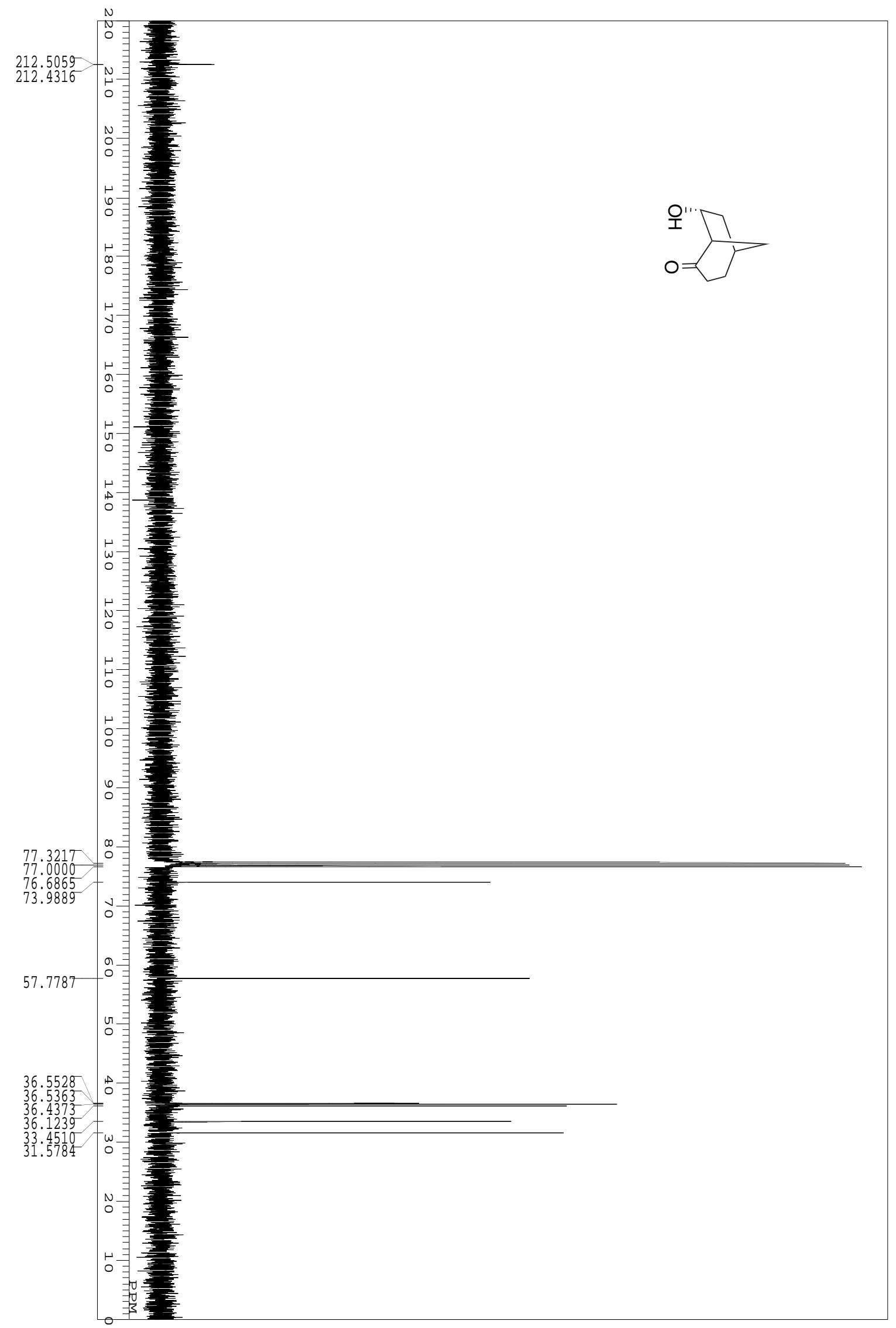

S-35 


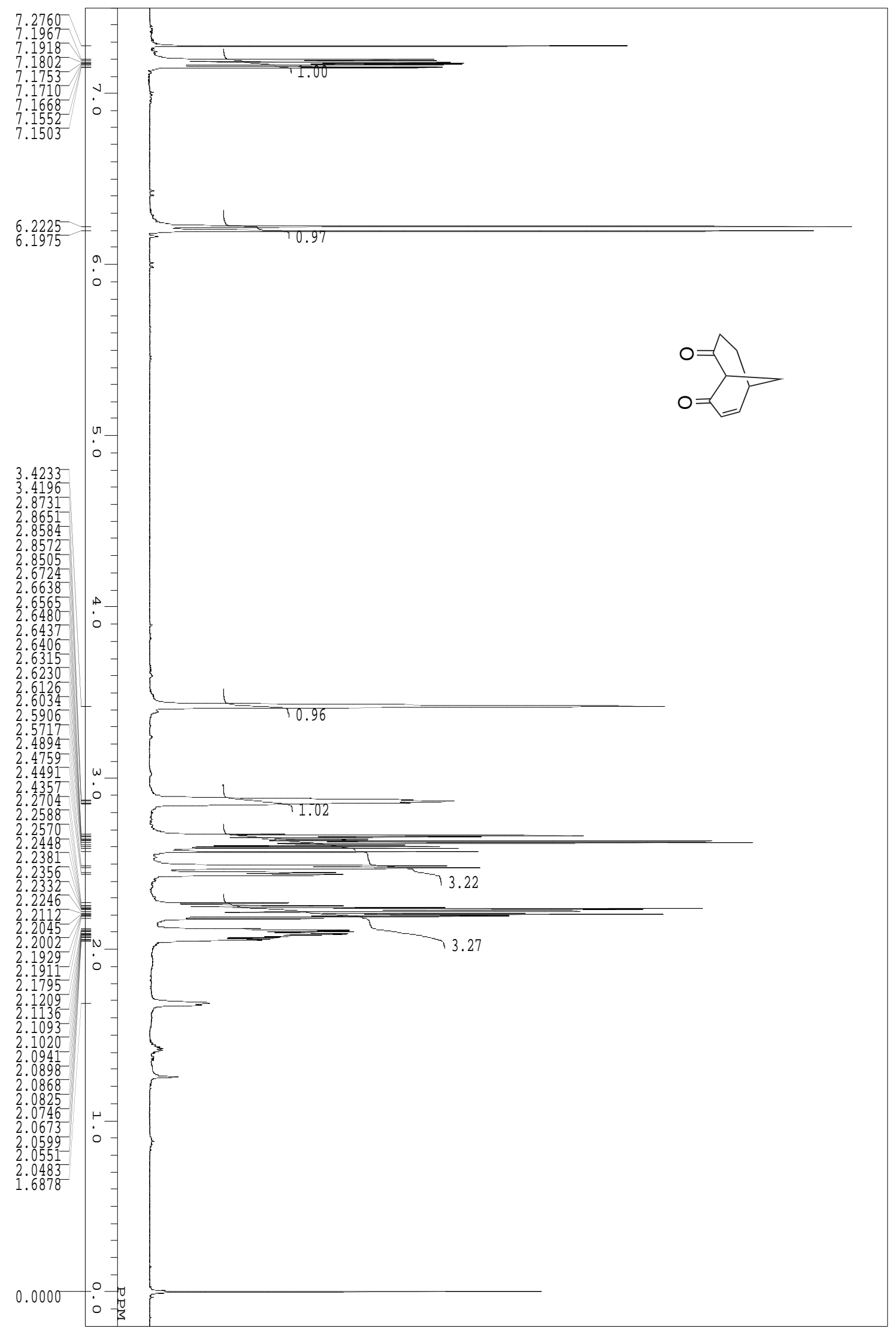




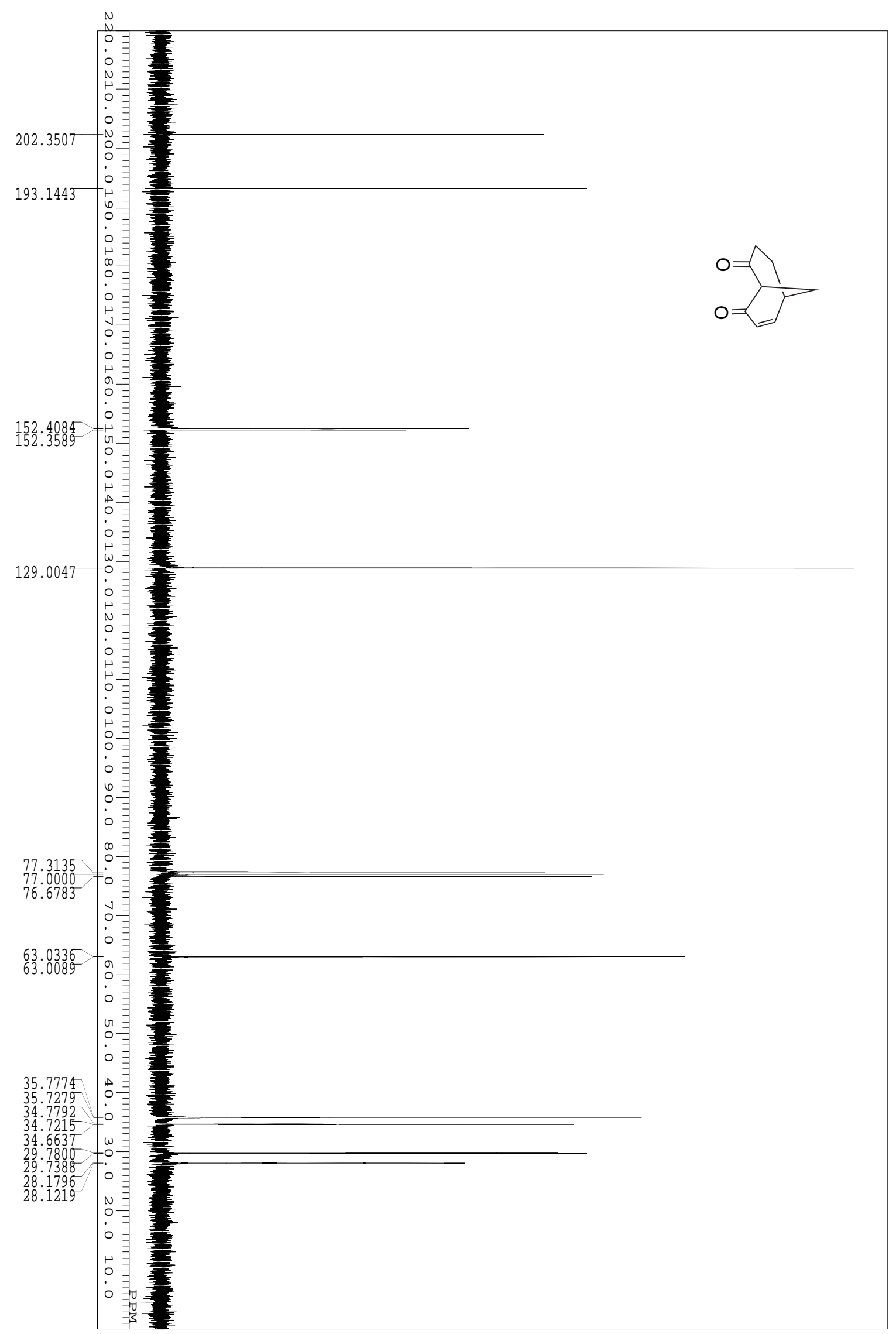




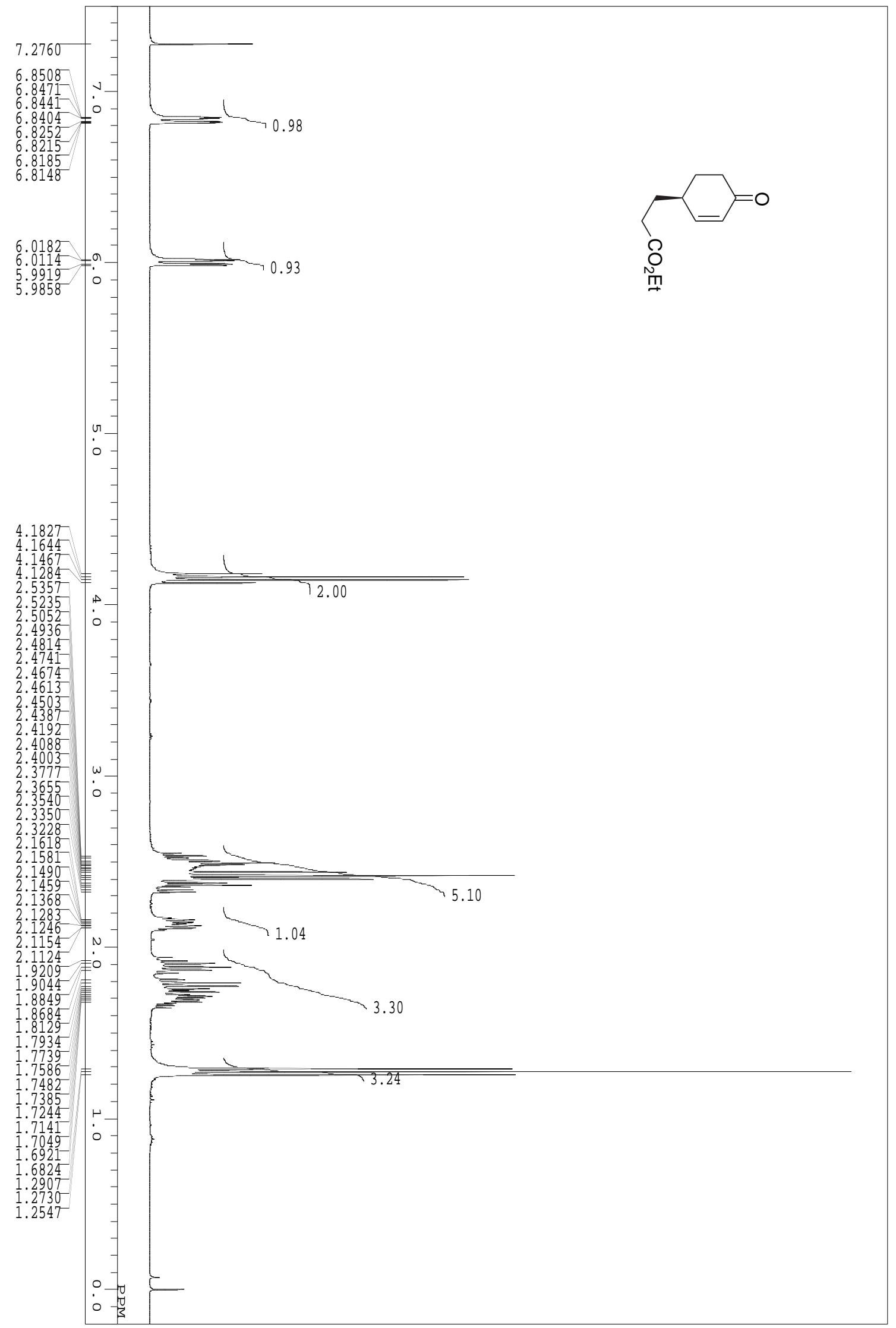




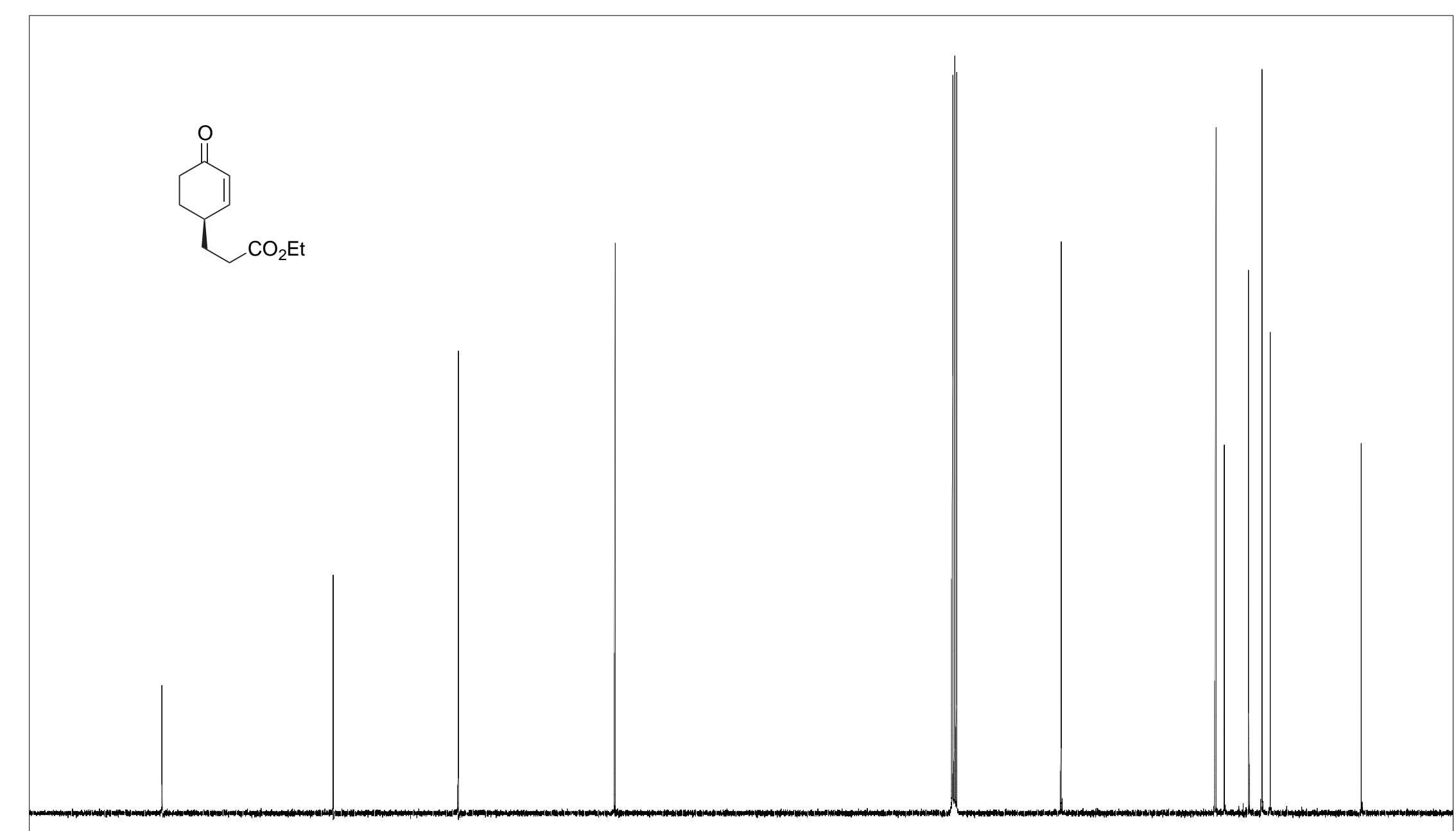

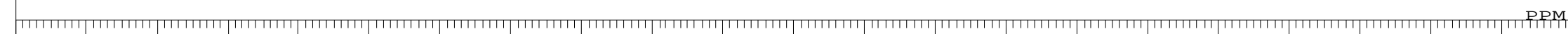
$220.0210 .0200 .0190 .0180 .0170 .0160 .0150 .0140 .0130 .0120 .0110 .0100 .090 .080 .070 .060 .0 \quad 50.0 \quad 40.0 \quad 30.0 \quad 20.0 \quad 10.0$

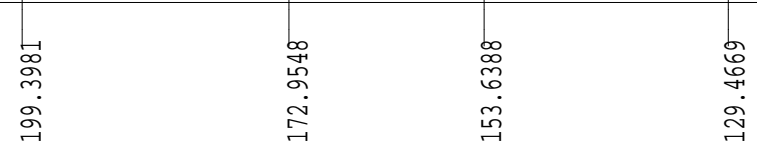

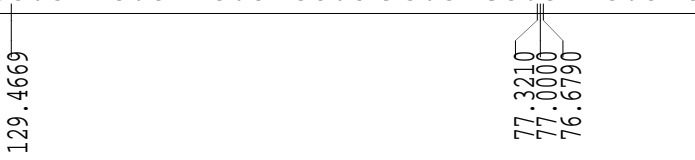

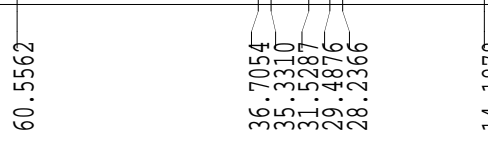




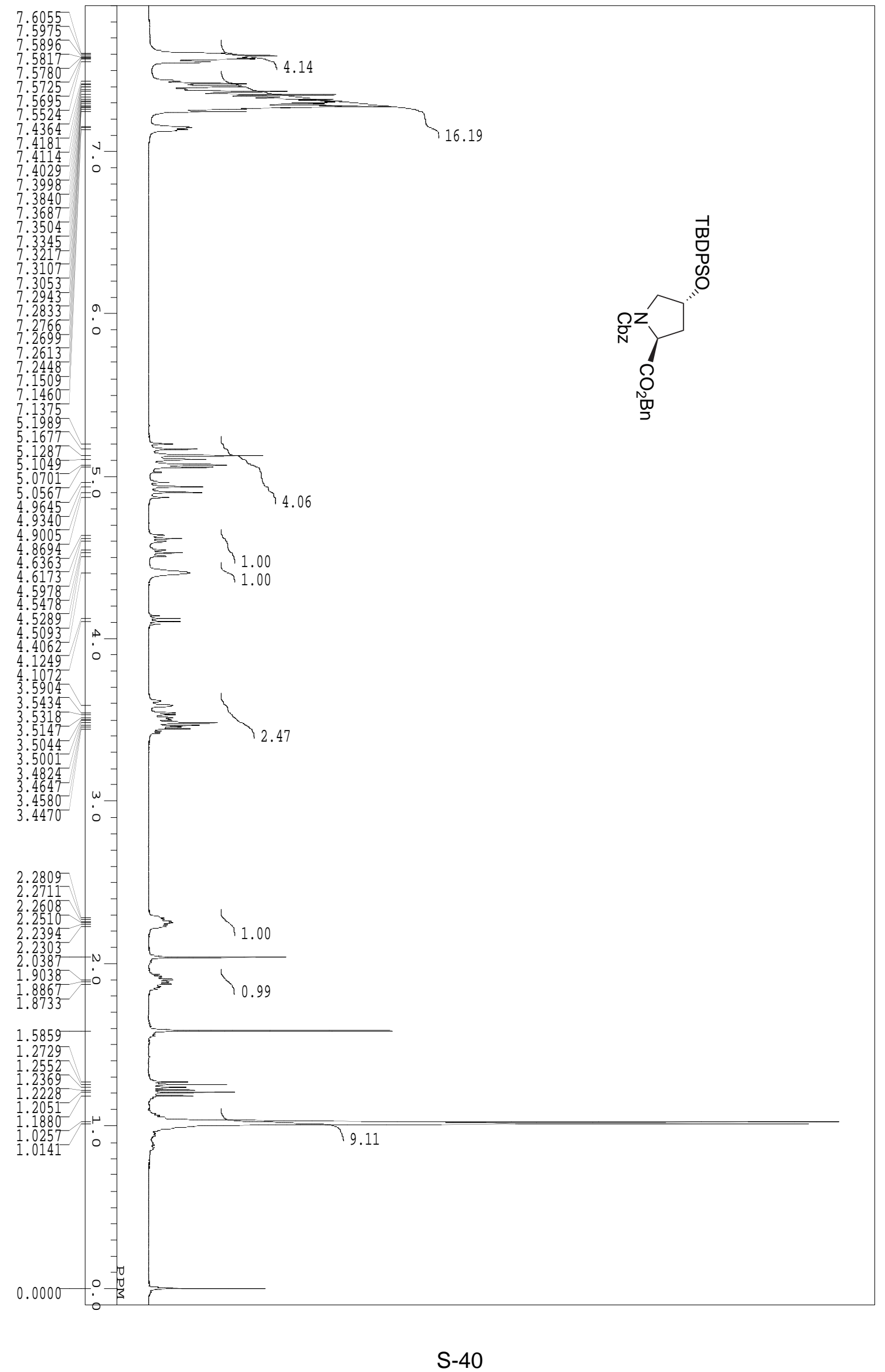




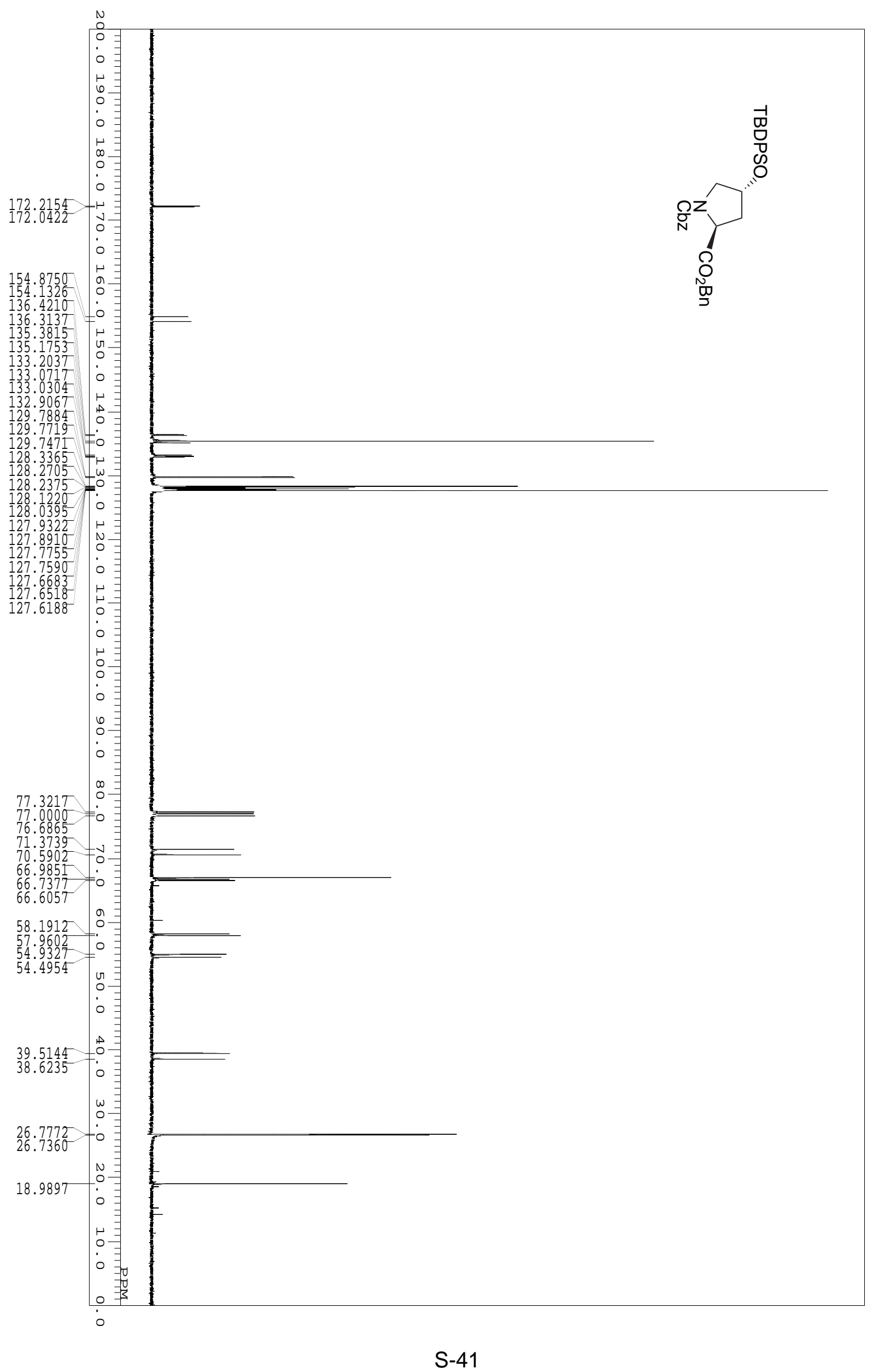




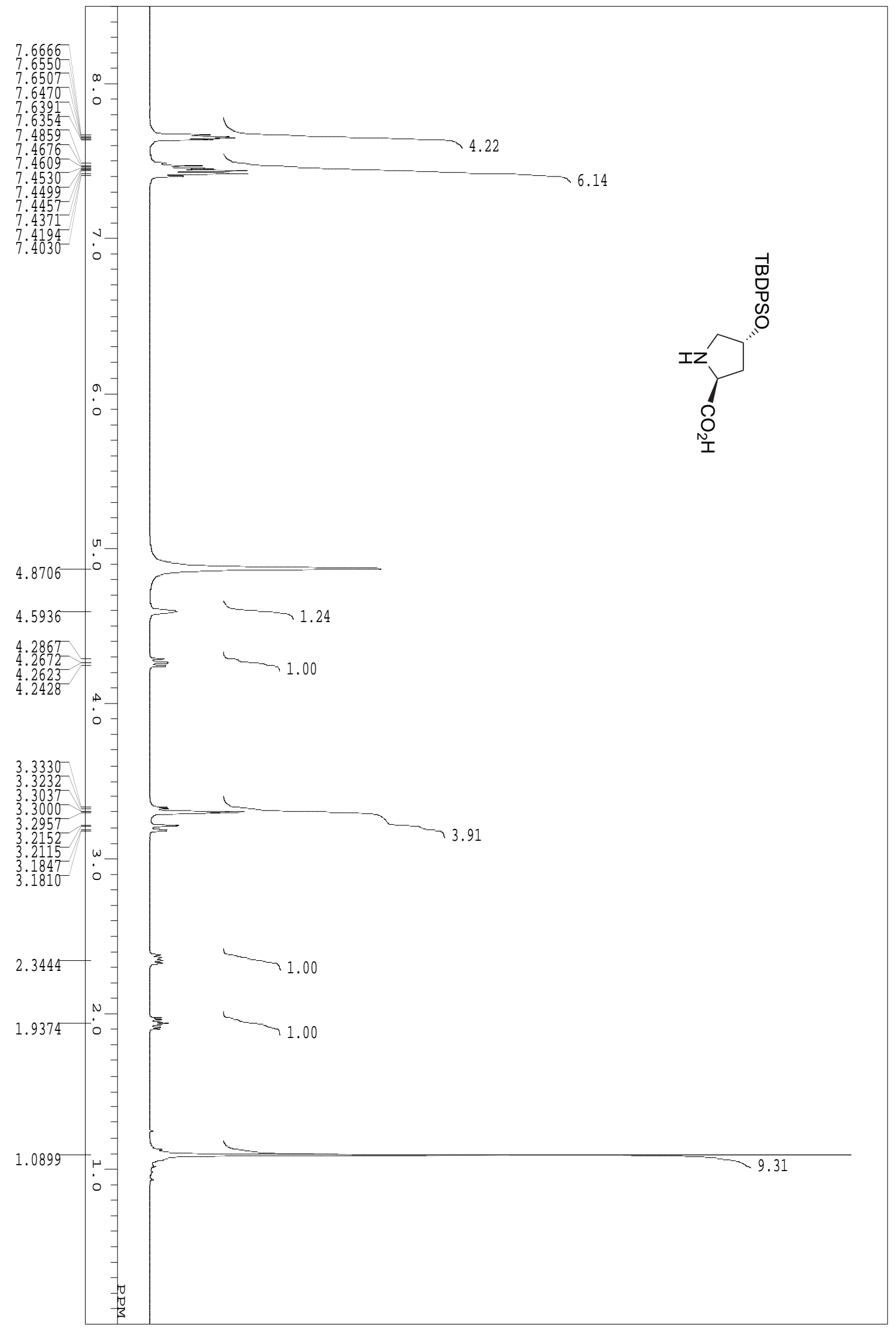




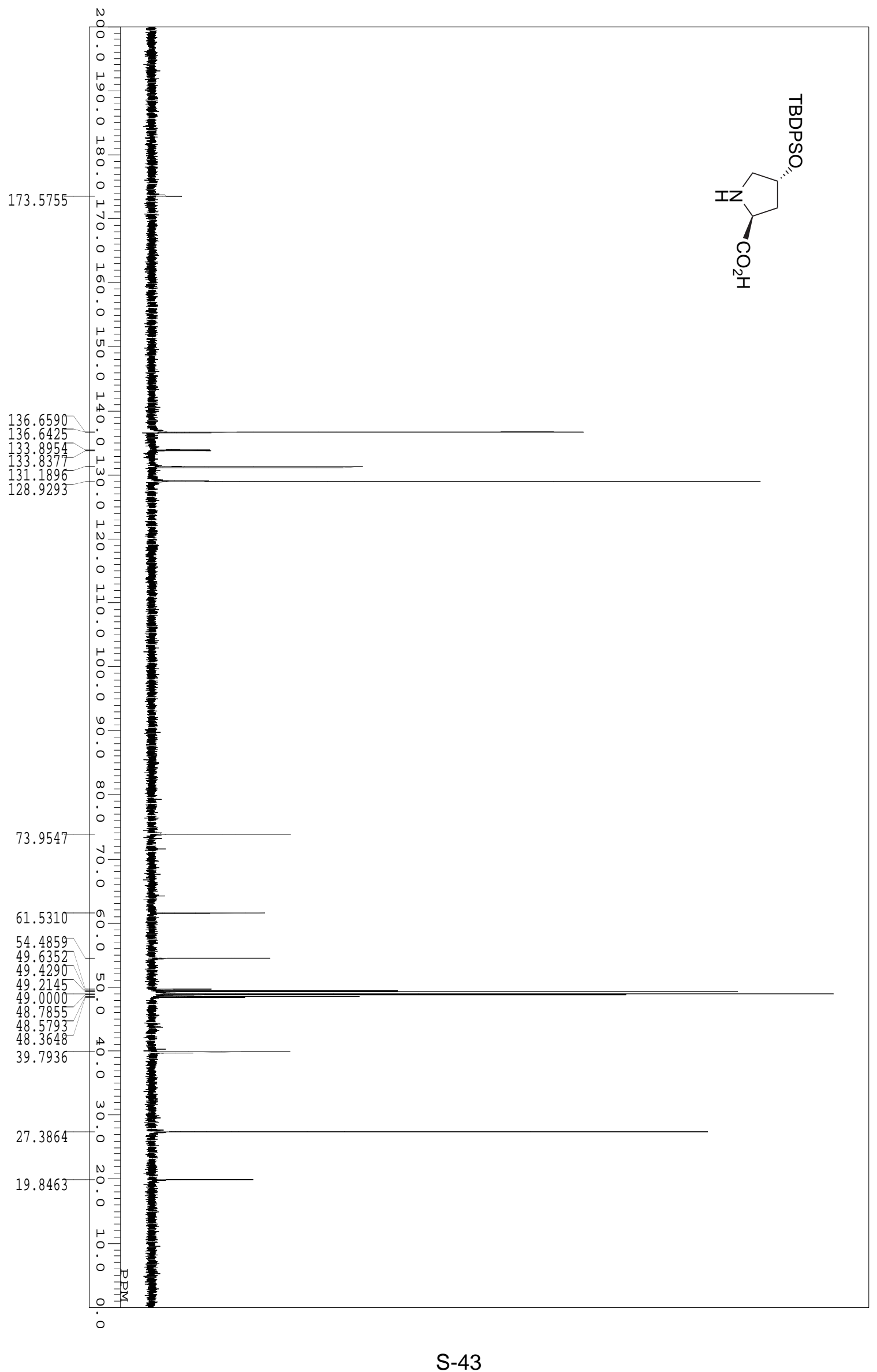




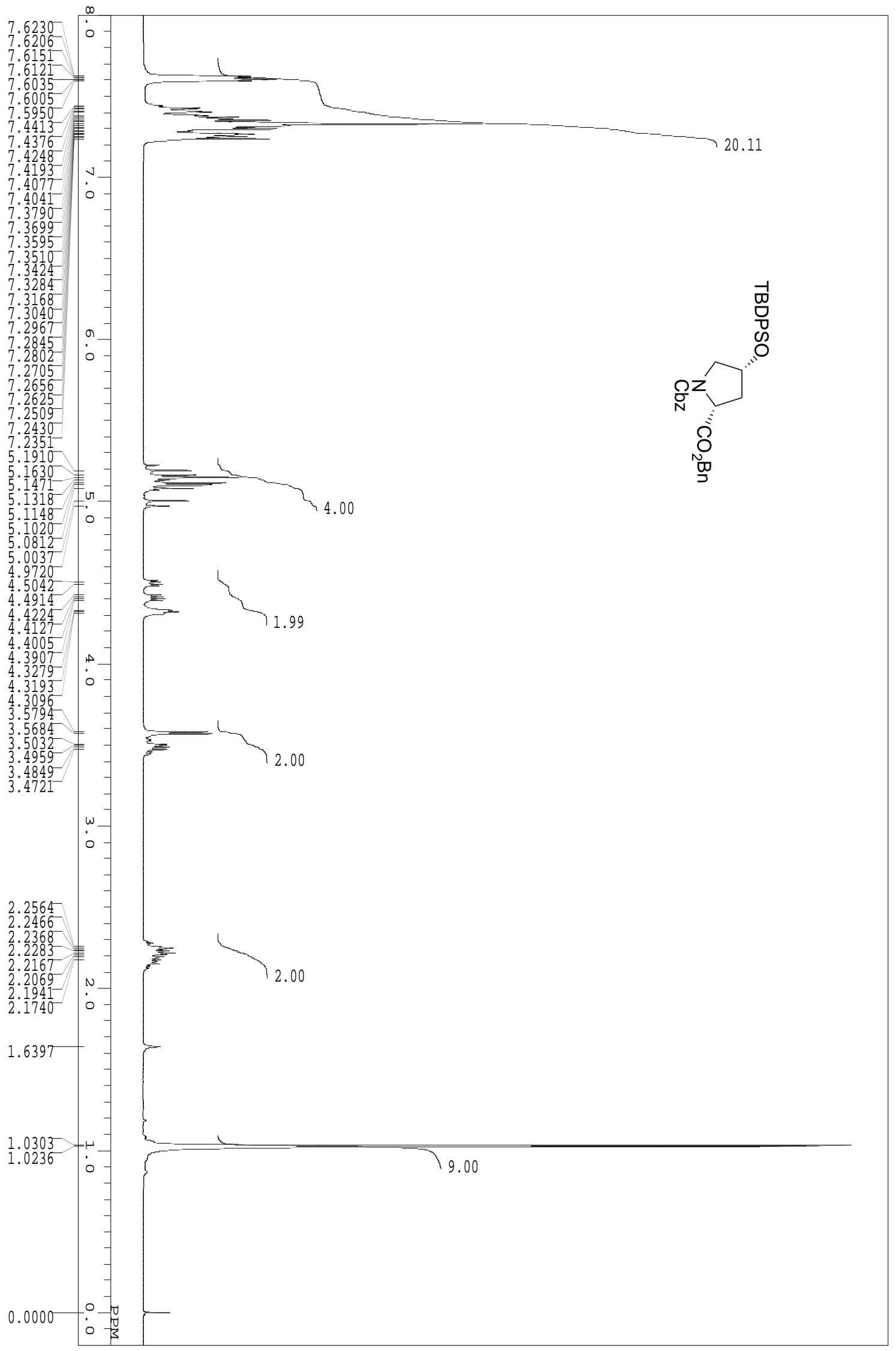




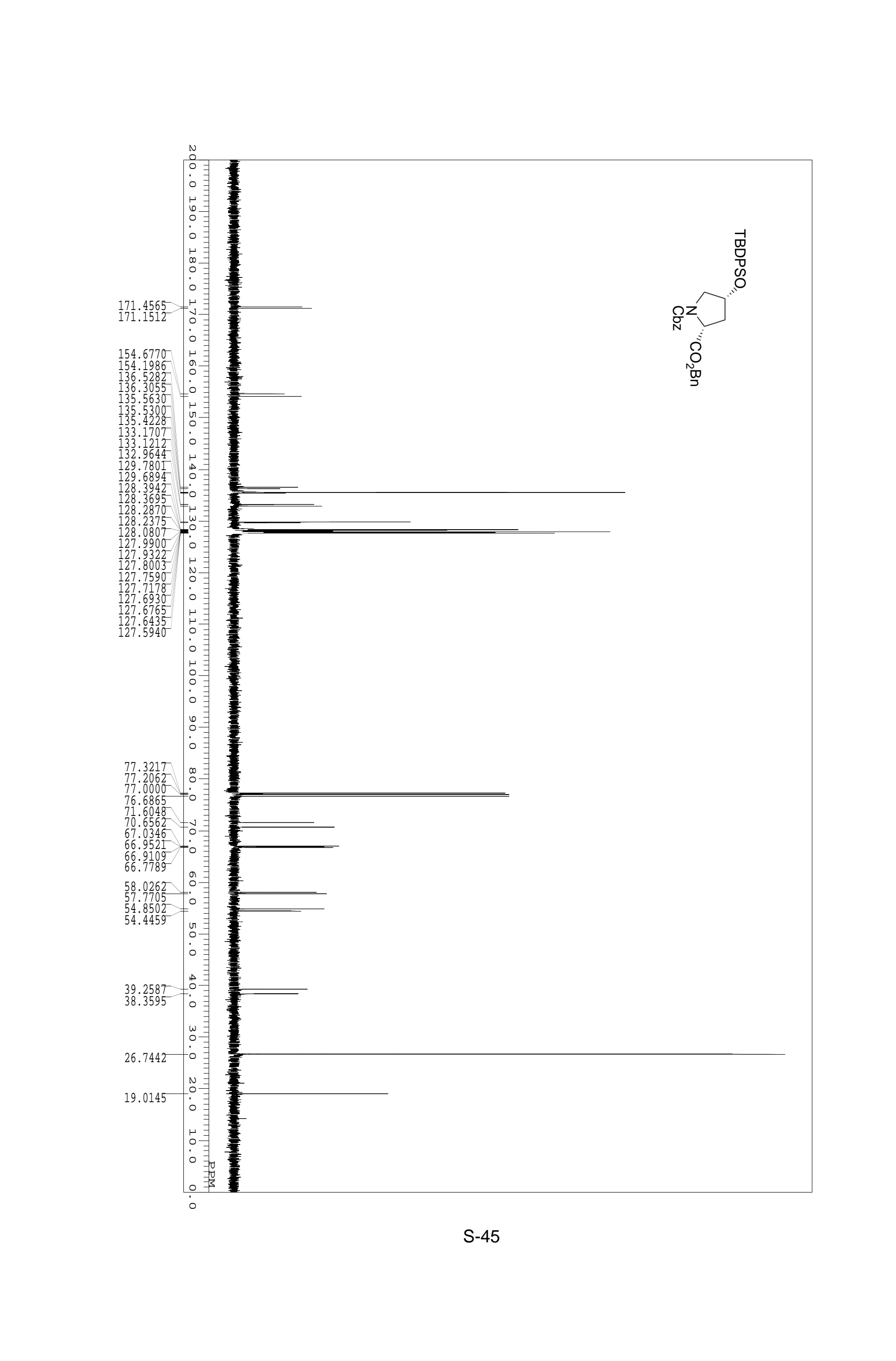




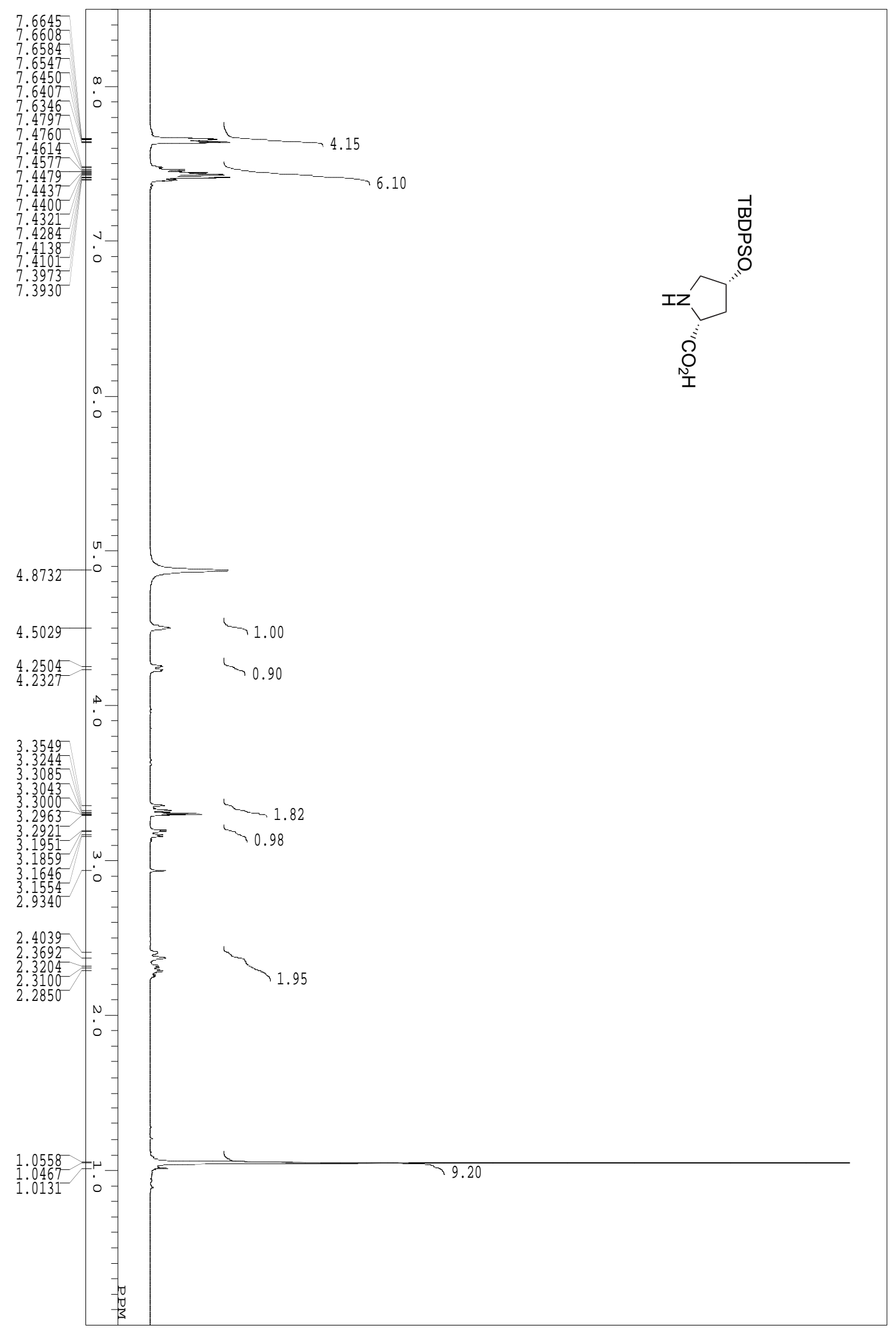




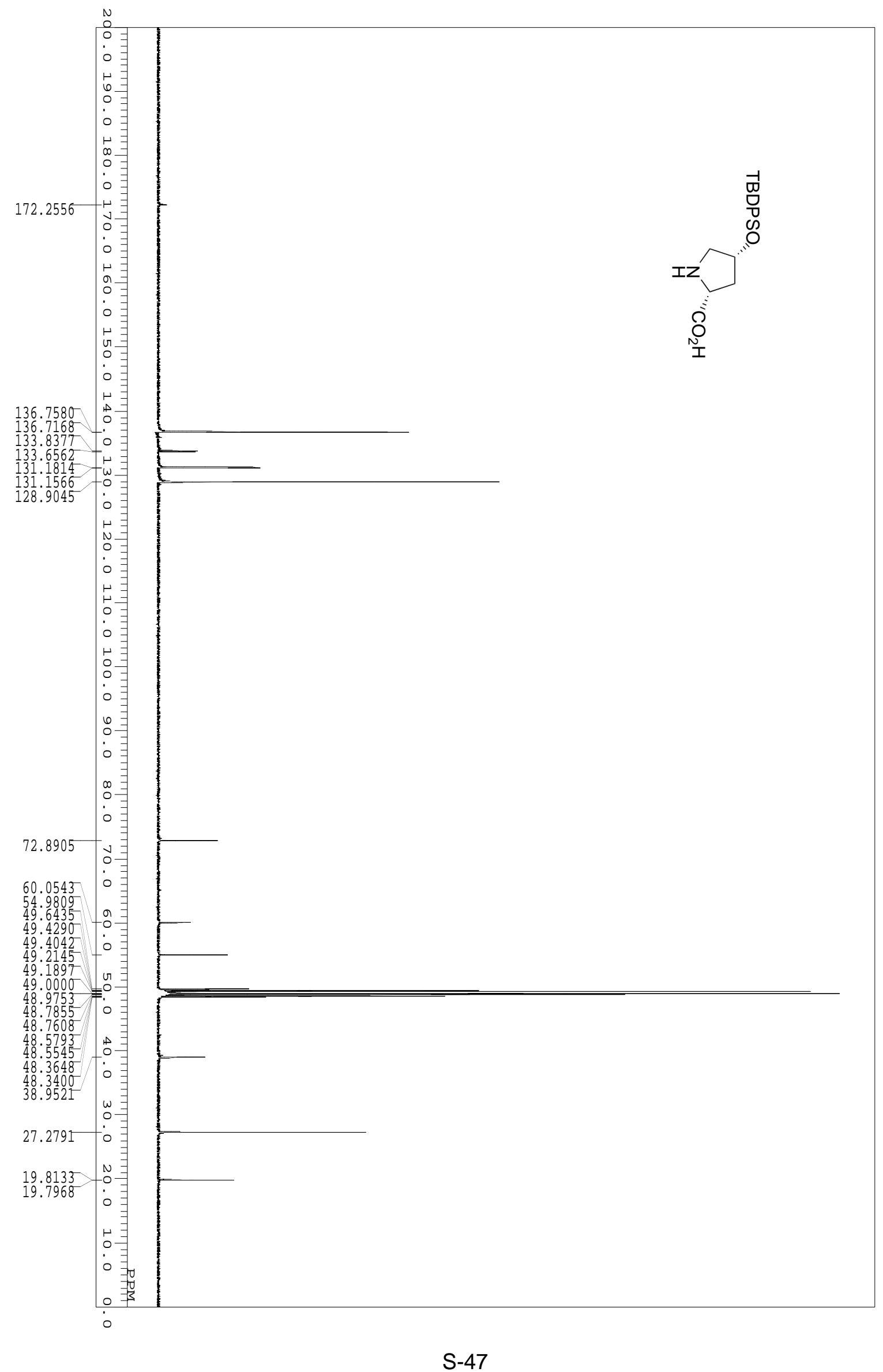




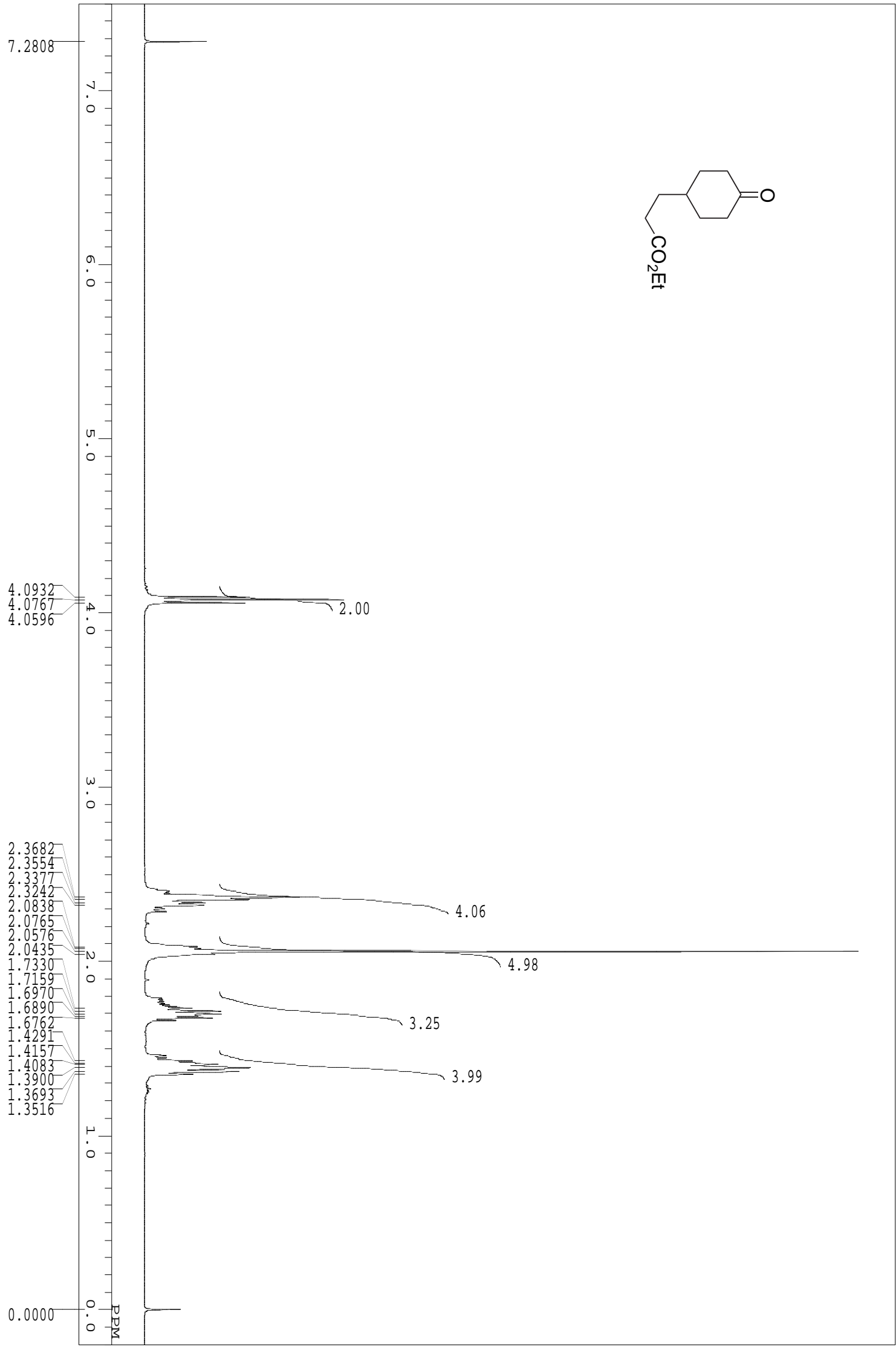




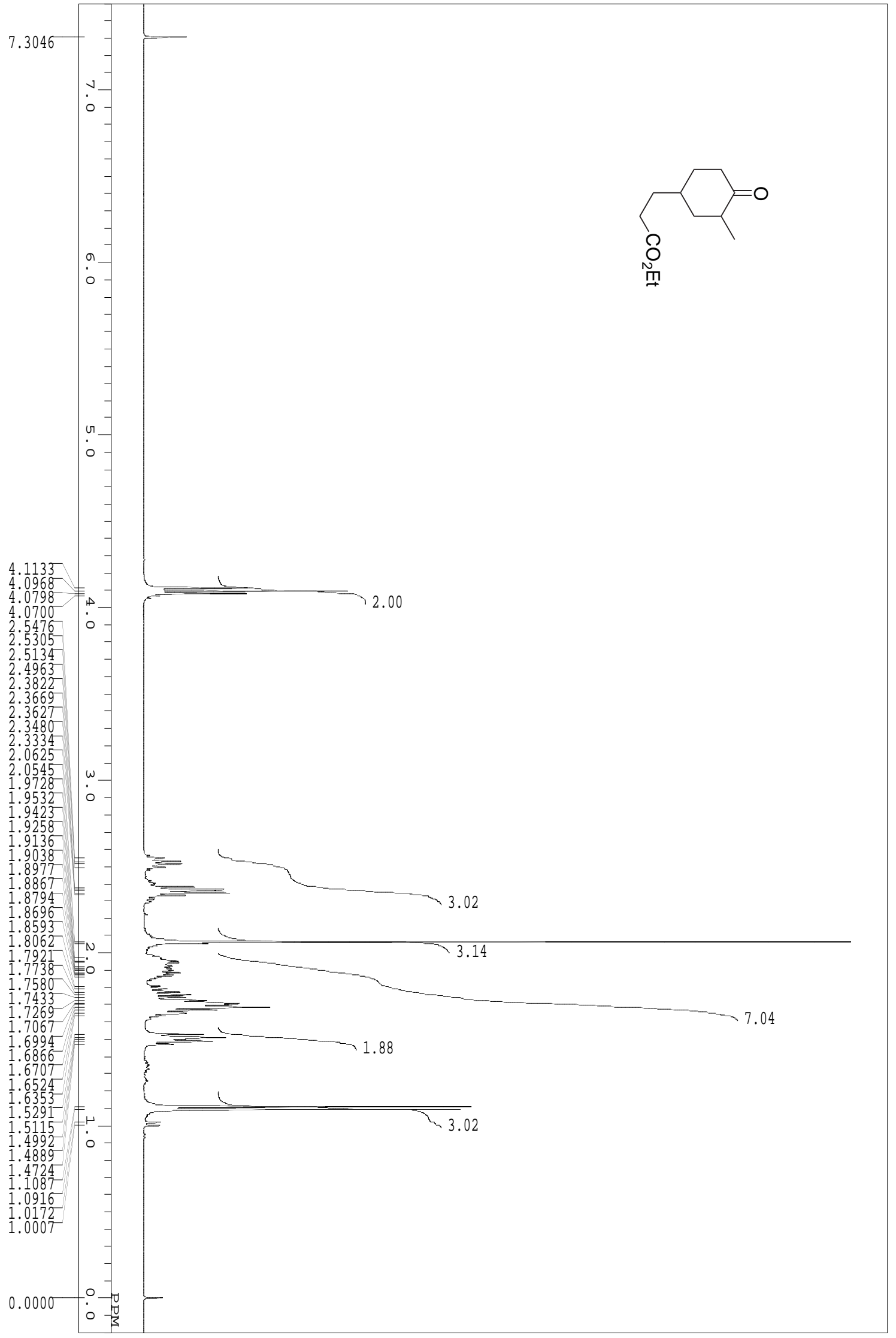




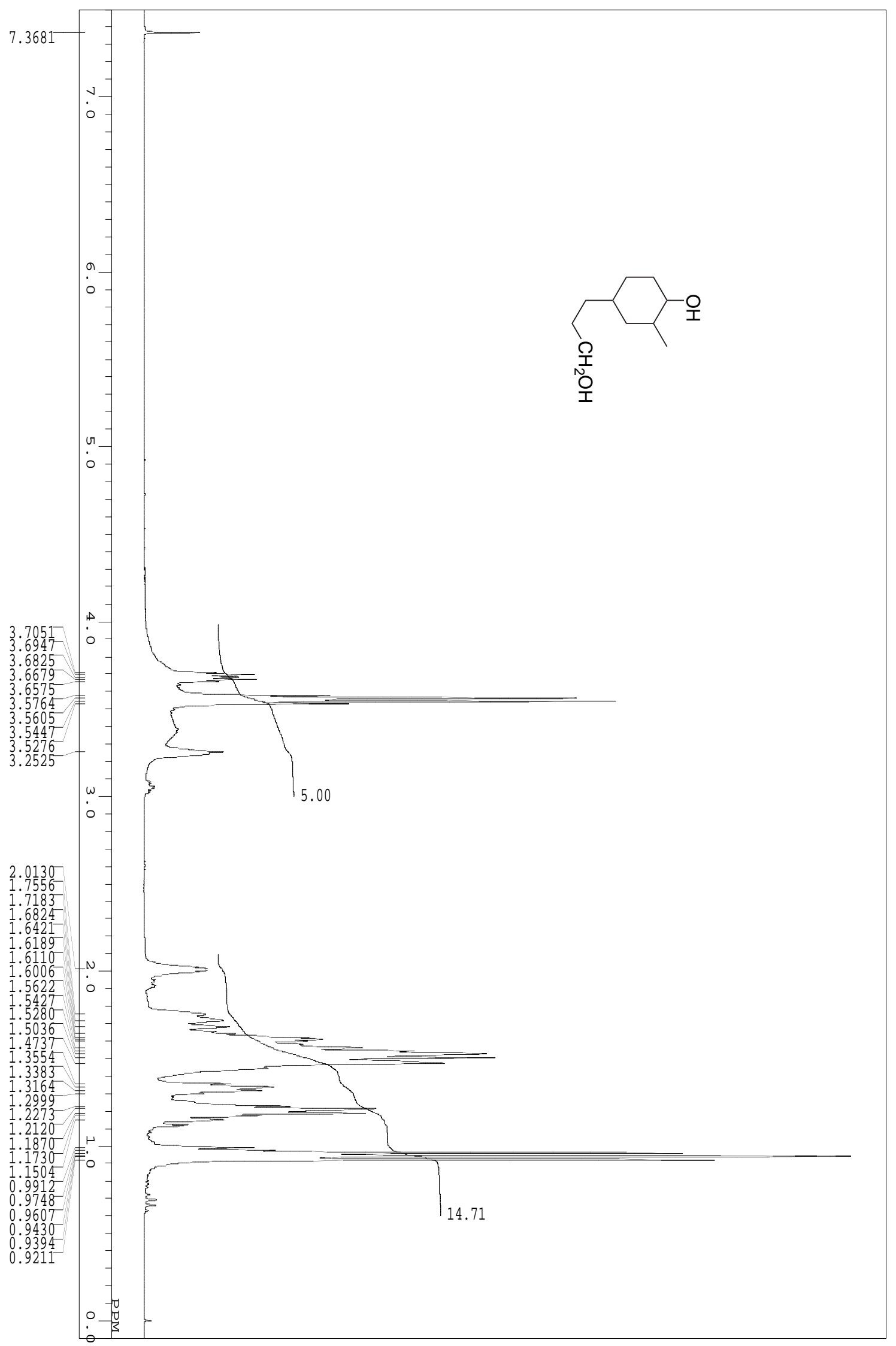

S-51 


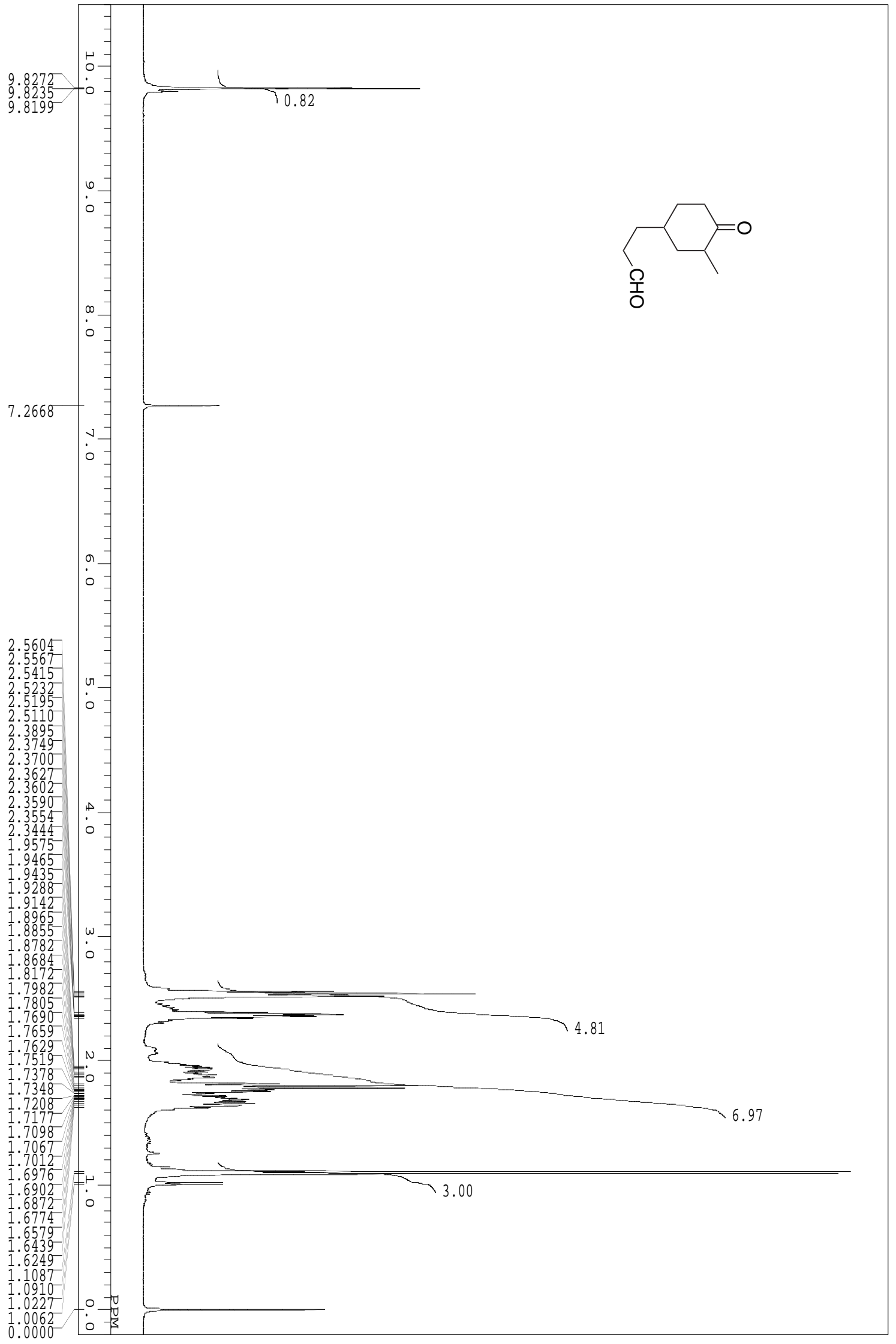

